4 norden 



\section{Nordisk Pendlingskarta}

Delrapport 4 - Sverige och Finland 


\section{Nordisk Pendlingskarta \\ Delrapport 4 - Sverige och Finland}

TemaNord 2005:503

(C) Nordisk Ministerråd, København 2005

ISBN 92-893-1115-0

Tryk: Ekspressen Tryk \& Kopicenter

Tilrettelæggelse: Publikationsenheden, Nordisk Ministerråd

Oplag: Print on demand

Trykt på miljøvenligt papir som opfylder kravene i den nordiske miljøsvanemærkeordning.

Publikationen kan bestilles på www.norden.org/order. Flere publikationer på

www.norden.org/publikationer

Printed in Denmark

Nordisk Ministerråd

Store Strandstræde 18

DK-1255 København K

Telefon $(+45) 33960200$

Telefax $(+45) 33960202$

\section{Nordisk Råd}

Store Strandstræde 18

DK-1255 København K

Telefon $(+45) 33960400$

Telefax $(+45) 33111870$

www.norden.org

Det nordiske samarbejde

Det nordiske samarbejde er et af de ældste og mest omfattende regionale samarbejder i verden. Det omfatter Danmark, Finland, Island, Norge og Sverige samt Færøerne, Grønland og Åland. Samarbejdet styrker samhørigheden mellem de nordiske lande med respekt for de nationale forskelle og ligheder. Det øger mulighederne for at hævde Nordens interesser i omverdenen og fremme det gode naboskab.

Samarbejdet blev formaliseret i 1952 med Nordisk Råds oprettelse som forum for parlamentarikerne og regeringerne i de nordiske lande. I 1962 underskrev de nordiske lande Helsingforsaftalen, som siden har været den grundlæggende ramme for det nordiske samarbejde. I 1971 blev Nordisk Ministerråd oprettet som det formelle forum til at varetage samarbejdet mellem de nordiske regeringer og de politiske ledelser i de selvstyrende områder, Færøerne, Grønland og Åland. 


\section{Innehåll}

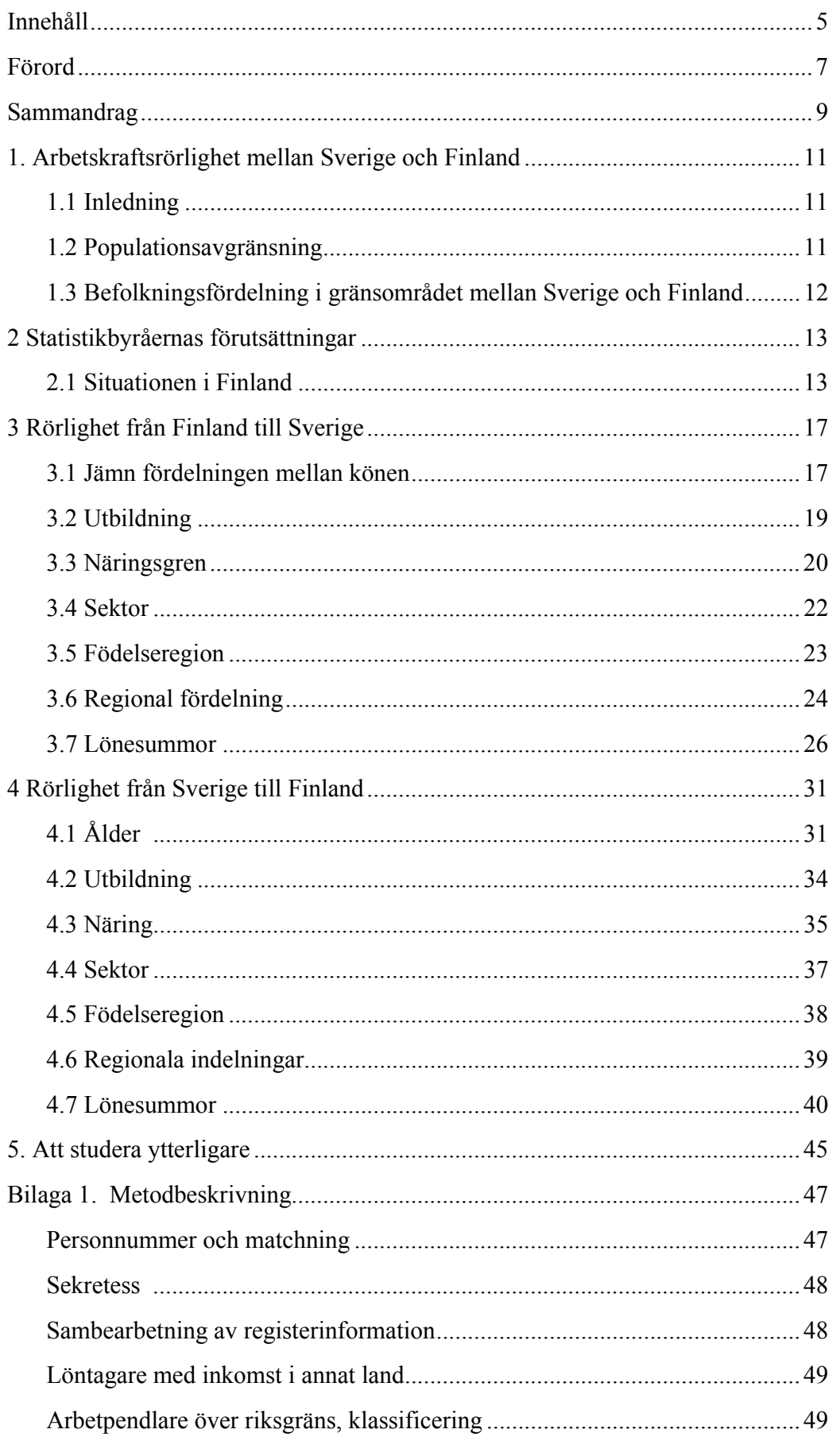





\section{Förord}

Sedan mer än femtio år har det funnits ambitioner inom det nordiska samarbetet att utveckla förutsättningar för en väl fungerande nordisk arbetsmarknad. En del i detta kan vara att förbättra kunskapen om hur rörlighet och samverkan över riksgränserna ser ut på den nordiska arbetsmarknaden. De statistiska redovisningar med nordiskt perspektiv som hittills presenterats har i huvudsak byggt på sammanställningar av befintliga nationella data. Med det här projektet "Nordisk pendlingskarta" har fyra nordiska statistikmyndigheter fått möjlighet att sambearbeta data. Syftet med samarbetet har varit att beskriva den gränsöverskridande arbetsmarknaden under 2001. Utbyte av data mellan myndigheterna har föregåtts av en särskild prövning i varje land.

Resultaten redovisas på nationell, regional och kommunal nivå och därmed beskrivs även rörligheten inom de nordiska gränsregionerna. Tidigare har gränsöverskridande statistik om arbetspendling redovisats för Öresundsregionen. Det är första gången en samlad redovisning på nationell nivå nu presenteras.

Projektet Nordisk pendlingskarta 2001 genomförs i samverkan mellan Danmarks Statistik, Statistiska Centralbyrån i Sverige, Statistisk Sentralbyrå i Norge och Statistikcentralen i Finland. Projektet omfattar fyra avsnitt avseende pendling mellan Sverige och Norge, Danmark och Sverige, Norge och Danmark samt Sverige och Finland. Resultaten kommer att sammanfattas i en huvudrapport.

Arbetet med metoder, beräkningar och redovisningar i denna rapport av pendling mellan Sverige och Finland har utförts av Kaija Ruotsalainen vid Statistikcentralen i Finland samt Carl-Gunnar Hanaeus, Maria Håkansson och Gunnar Hedin vid Statistiska Centralbyrån. Berndt Hermansson vid Statistiska centralbyrån i Örebro har varit koordinator för projektet.

För finansiering av projektet samt för tryck och distribution av rapporten svarar Nordiska Ministerrådet. 



\section{Sammandrag}

I denna rapport redovisas rörligheten mellan den finska och den svenska arbetsmarknad i form av arbetsströmmar över riksgräns mellan de båda länderna. Rörligheten redovisas i rapporten dels som antalet löntagare, dels som antalet arbetspendlare över riksgräns. Med löntagare avses personer som erhållit någon form av löneutbetalning i grannlandet. Med arbetspendlare avses personer som har sin huvudsakliga löneinkomst i det land de pendlar till. I rapporten redovisas även lönesummans storlek för de olika grupperna. Lönesumman står för det summerade beloppet av utbetalda löner enligt arbetsgivarnas kontrolluppgifter eller motsvarande för grupper av människor som bor i t.ex. en kommun. Redovisningen av lönesumman syftar till att ge en bild av den ekonomiska betydelsen av den gränsöverskridande verksamheten i stort. I tabeller där det förekommer både svenska och finska löneinkomster så är euron omräknad till svenska kronor.

\section{0 personer hade löneinkomst $i$ grannlandet}

Totalt 10500 personer hade löneinkomster från grannlandet. Av dessa bodde 6300 i Finland och 4200 i Sverige. Se tabell 1. I procent motsvaras det av 60 respektive 40 procent. Det totala antalet arbetspendlare var 4 100. Av dessa bodde 61 procent i Finland och 39 procent i Sverige. Förhållandet mellan löneinkomsttagare och arbetspendlare i fördelningen var således i princip lika mellan de båda länderna.

Tabell 1. Personer folkbokförda i Sverige med löneinkomster i Finland, respektive folkbokförda i Finland med löneinkomster i Sverige, år 2001. SEK

\begin{tabular}{|c|c|c|c|c|c|c|c|c|c|c|}
\hline \multirow{2}{*}{$\begin{array}{l}\text { Folkbok- } \\
\text { förings- } \\
\text { land }\end{array}$} & \multicolumn{5}{|c|}{ Med löneinkomst i grannlandet } & \multicolumn{5}{|c|}{ därav arbetspendlare över riksgräns } \\
\hline & $\begin{array}{l}\text { Antal } \\
\text { personer }\end{array}$ & $\begin{array}{l}\text { löne- } \\
\text { summan } \\
\text { i Sverige } \\
\text { i mkr }\end{array}$ & $\begin{array}{l}\text { genom- } \\
\text { snittlig } \\
\text { löneinkomst } \\
\text { i Sverige }\end{array}$ & $\begin{array}{l}\text { löne- } \\
\text { summan } \\
\text { i Finland } \\
\text { i mkr }\end{array}$ & $\begin{array}{l}\text { genom- } \\
\text { snittlig } \\
\text { löneinkomst } \\
\text { i Finland }\end{array}$ & $\begin{array}{l}\text { antal } \\
\text { personer }\end{array}$ & $\begin{array}{l}\text { löne- } \\
\text { summan } \\
\text { i Sverige } \\
\text { i mkr }\end{array}$ & $\begin{array}{l}\text { genom- } \\
\text { snittlig } \\
\text { löneinkomst } \\
\text { i Sverige }\end{array}$ & $\begin{array}{l}\text { löne- } \\
\text { summan } \\
\text { i Finland } \\
\text { i mkr }\end{array}$ & $\begin{array}{l}\text { genom- } \\
\text { snittlig } \\
\text { löneinkomst } \\
\text { i Finland }\end{array}$ \\
\hline Finland & 6335 & 611 & 96400 & 744 & 117490 & 2525 & 436 & 172700 & 50 & 19990 \\
\hline Sverige & 4206 & 615 & 146255 & 408 & 96900 & 1599 & 3 & 1965 & 248 & 155900 \\
\hline
\end{tabular}

Den totala lönesumman för personer med löneinkomst i grannlandet uppgick till 1 miljard SEK fördelade på 610 miljoner SEK för finländare med löneinkomst i Sverige och ca 410 miljoner SEK för svenskar med löneinkomst i Finland. I relativa tal betyder det att 60 procent av den totala lönesumman fördelades på löntagare boende i Finland och 40 procent på löntagare boende i Sverige. 
Den totala lönesumman för arbetspendlarna uppgick till 670 miljoner SEK, varav 65 procent hade intjänats av finländare i Sverige och 35 procent av svenskar i Finland. Den genomsnittliga löneinkomsten i Sverige för finländare var således något högre än svenskarnas i Finland.

I relation till övrig pendling över riksgräns som ingår i undersökningen var arbetsströmmarna betydligt större mellan Sverige och Norge. Den stod för ca 50 procent av samtliga arbetsströmmar över riksgräns i Norden. Arbetsströmmarna mellan Finland och Sverige samt mellan Danmark och Sverige var ungefär lika stora och omfattade vardera knappt 20 procent av de totala arbetsströmmarna i Norden. 


\section{Arbetskraftsrörlighet mellan Sverige och Finland}

\subsection{Inledning}

Rörligheten mellan nationella arbetsmarknader kan beskrivas utifrån olika betraktelsesätt exempelvis genom:

- löneinkomster/löntagareinkomster

- antalet löntagare

- förvärvsarbetande som arbetspendlare över riksgräns

- studerande över riksgräns

- flyttare

Projektet Nordisk pendlingskarta utgår från arbetsmarknads- och rörlighetsperspektiv, d.v.s. rörlighet över riksgräns relaterat till förvärvsarbete. Denna rapport redovisar antalet personer i Finland och i Sverige som under 2001 har haft en löneinkomst i grannlandet och vilka av dessa personer som har klassificerats som "arbetspendlare över riksgräns". Redovisningen omfattar även lönesumman för löneinkomsttagarna och för arbetspendlarna över riksgräns. Dessutom redovisas bakgrundsvariabler som kön, ålder, födelseregion, utbildningsnivå och näringsgren.

\subsection{Populationsavgränsning}

Populationen i undersökningen utgörs av personer som har erhållit löneutbetalningar under 2001 från en arbetsgivare i grannlandet. Det innebär att en person som är folkbokförd i Sverige och som arbetar för ett svenskt företag i Finland och som får lönen av sin arbetsgivare i Sverige inte ingår $\mathrm{i}$ redovisningen. Företagare som utför arbete $\mathrm{i}$ grannlandet för sin egen firma ingår inte heller i redovisningen eftersom det inte heller för denne skapas någon kontrolluppgift för detta arbete.

I föreliggande rapport redovisas två olika populationer. Den ena avser löneinkomsttagare och den andra arbetspendlare över riksgräns.

Löneinkomsttagare är personer som haft minst en löneinkomst under ett visst år enligt kontrolluppgifter $i$ arbetslandet.

Arbetspendlare över riksgräns är personer som i Sverige haft ett lönearbete under minst 4 timmar i november månad under ett visst år. I Finland är mätmånaden december. Dessutom gäller att personens eventuella inkomst i hemlandet för det aktuella kalenderåret inte får överstiga den $i$ arbetslandet. Arbetspendlare är en delmängd av löneinkomsttagare. 


\subsection{Befolkningsfördelning i gränsområdet mellan Sverige och Finland}

Finland landgräns i norr mot Sverige utgörs i princip av Tornedalen. Gränsregionen är relativt glest befolkad men utgör i huvudsak ett gemensamt kulturellt område. Exempelvis är nästan hälften av befolkningen i arbetsför ålder i den svenska gränskommunen Haparanda född i Finland. I övrigt åtskiljs Sverige och Finland av de stora vattnen Bottenviken, Norra Kvarken, Bottenhavet och Södra Kvarken. De befolkningstäta områdena i sydvästra Finland och Stockholms och Uppsala län i Sverige avgränsas av ett skärgårdshav med Åland i centrum. Den fria nordiska arbetsmarknaden har haft stor betydelse för relationerna mellan Finland och Sverige. Under andra hälften av 1900-talet var det en omfattande arbetskraftsvandring från Finland till Sverige. År 2003 fanns det exempelvis 190000 personer som var folkbokförda i Sverige med Finland som födelseland. 


\section{Statistikbyråernas förutsättningar}

Genom att statistiksystemen i de nordiska länderna till stora delar är registerbaserade finns förutsättningar för att framställa regional pendlingsstatistik över riksgräns. Det innebär inte att det har varit enkelt att hitta lösningar för att sambearbeta material från de olika länderna. Varje land har sin uppläggning av statistiken och skillnaderna har blivit tydliga $i$ detta samarbete. Olikheterna har varit möjliga att hantera.

Någon särskild datainsamling har inte gjorts för att kunna genomföra projektet. Underlaget utgörs helt av de administrativa data som finns tillgängliga i respektive land. De uppgifter som används för att definiera de två huvudpopulationer som ingår i undersökningen består främst av de kontrolluppgifter som arbetsgivarna lämnar till skattemyndigheterna och av uppgifter från de centrala befolkningsregistren.

Personnumret är vanligtvis nyckeln till att sambearbeta individuppgifter från olika register. I det här sammanhanget är detta inte möjligt eftersom det saknas ett gemensamt nordiskt personnummer. Utbytet av material har omfattat födelsedatum, löpnummer och namn på de inkomsttagare i Sverige som inte är folkbokförda i Sverige och på motsvarande sätt för de inkomsttagare i Finland som inte är folkbokförda i Finland. Genom sambearbetning av uppgift om födelsedatum och namn har sedan de aktuella personerna kunnat identifieras i det mottagande landet.

\subsection{Situationen i Finland}

Det material över arbetspendling som finns tillgängligt i Finland avviker från de övriga nordiska ländernas material. I Finland är uppgifterna om arbetspensionsförsäkring den främsta källan för anställningsuppgifterna, medan den huvudsakliga källan i de övriga nordiska länderna är skattemyndigheternas kontrolluppgifter. I Finland innehåller skattemyndigheternas material inte uppgifter om datum eller arbetsställe, varför det inte kan användas ensamt. Skattemyndigheternas material används närmast för att komplettera bristande inkomstuppgifter ur den privata sektorns material.

De huvudsakliga källorna för anställningsuppgifter i Finland är:

- Den privata sektorns anställningsuppgifter, som erhålls från

Pensionsskyddscentralen 
- Kommunsektorns anställningsuppgifter från Kommunernas pensionsförsäkring

- Den statliga sektorns anställningsuppgifter från Statskontoret

Därtill används några andra material över anställningsförhållanden, som inte ingår i ovannämnda pensionsförsäkringssystem. Deras andel av hela arbetspensionssystemet är liten och i den här granskningen har de utelämnats med undantag för material från Ålands landskapsstyrelse, som kan ha betydelse i granskningen mellan Finland och Sverige.

Den kommunala och statliga sektorns material över anställningsförhållanden innehåller förutom uppgifter om datum också uppgifter om de utbetalda lönerna. Den privata sektorns anställningsmaterial innehåller inte uppgifter om inkomster, utan man har försökt hänföra löneuppgiften på personerna ur skattemyndigheternas material. Ur skattemyndigheternas material användes årsanmälningsuppgifter både om de allmänt skattskyldiga och de begränsat skattskyldiga. I regel är personer, som bor utanför Finland och vars arbetsplats är i Finland, begränsat skattskyldiga. I vissa undantagsfall kan personerna också höra till allmänt skattskyldiga. Personer som arbetar i Finland är huvudsakligen försäkrade i Finland, men ibland kan arbetspensionsförsäkring tas för personen också i bosättningslandet.

I princip borde det för personer som arbetar i Finland och bor utomlands hittas uppgifter om anställningsförhållandet i arbetspensionssystemet och löneuppgifter bland årsanmälningsuppgifterna om de begränsat skattskyldiga. I materialet över anställningsförhållanden fanns det dock omkring 2200 personer, som enligt skattemyndigheternas uppgifter inte fått lön av en finsk arbetsgivare (som begränsat skattskyldiga). Ungefär 1900 personer av dessa var dock med i materialet över allmänt skattskyldiga och närmare 1200 av dessa hade flyttat från Finland till Sverige under 2001. Således förklaras största delen av dessa motstridande uppgifter med att personen under året flyttat från Finland till Sverige och arbetat i Finland före flyttningen. Personen ifråga kan haft både ett anställningsförhållande (arbetspensionsförsäkring) i Finland och fătt lön som allmänt skattskyldig.

Det finns också motstridiga uppgifter åt motsatt håll. En person kan ingå i materialet över de begränsat skattskyldiga, men denne saknar enligt anställningsuppgifterna anställningsförhållande i Finland år 2001. Delvis förklaras detta med att anställningsförhållanden, som varat mindre än en vecka, slopats ur det anställningsmaterial som använts i denna utredning. Dessutom ingår inte de minsta anställningsmaterialen i de uppgifter som lämnats av Pensionsskyddscentralen, Statskontoret och Kommunernas pensionsförsäkring. I vissa undantagsfall kan arbetspensionsförsäkring tas i personens bosättningsland.

I denna utredning ingår alla de personer som i slutet av år 2001 bodde i Sverige och som detta år fick löneinkomst i Finland. Uppgifterna kom- 
mer antingen från skattemyndigheterna och avser allmänt och begränsat skattskyldiga eller från kommun- och statssektorns material i form av anställningsmaterialet. De personer som år 2001 bara hade ett gällande anställningsförhållande, men inga löneinkomster för året ingår inte i materialet. Vid granskning av resultaten bör man tänka på att materialet också omfattar de personer som under år 2001 flyttat till Sverige och som före flyttningen kan ha haft en arbetsplats i Finland. 



\section{Rörlighet från Finland till Sverige}

Avsnitt 3 redovisar strömmen av personer som år 2001 var folkbokförda i Finland och som arbetade i Sverige. I redovisningen används genomgående de två begreppen löneinkomsttagare och arbetspendlare, vilka beskrivs närmare i kapitel 1 samt i bilaga 1. Det var totalt 6335 personer som var folkbokförda i Finland och som hade lönearbete i Sverige 2001. Av dessa personer klassificerades 2525 som arbetspendlare. De finländska löneinkomsttagarna tjänade tillsammans 611 miljoner kronor i Sverige och den genomsnittliga löneinkomsten var 96400 SEK. Deras genomsnittliga löneinkomster för arbete i Finland var 117490 SEK.

De som klassificerades som arbetspendlare tjänade tillsammans 436 miljoner SEK i Sverige. Deras genomsnittliga löneinkomst i Sverige var drygt 173000 SEK och knappt 20000 SEK i Finland.

Tabell 2. Personer folkbokförda i Finland med inkomster i Sverige år 2001 i SEK

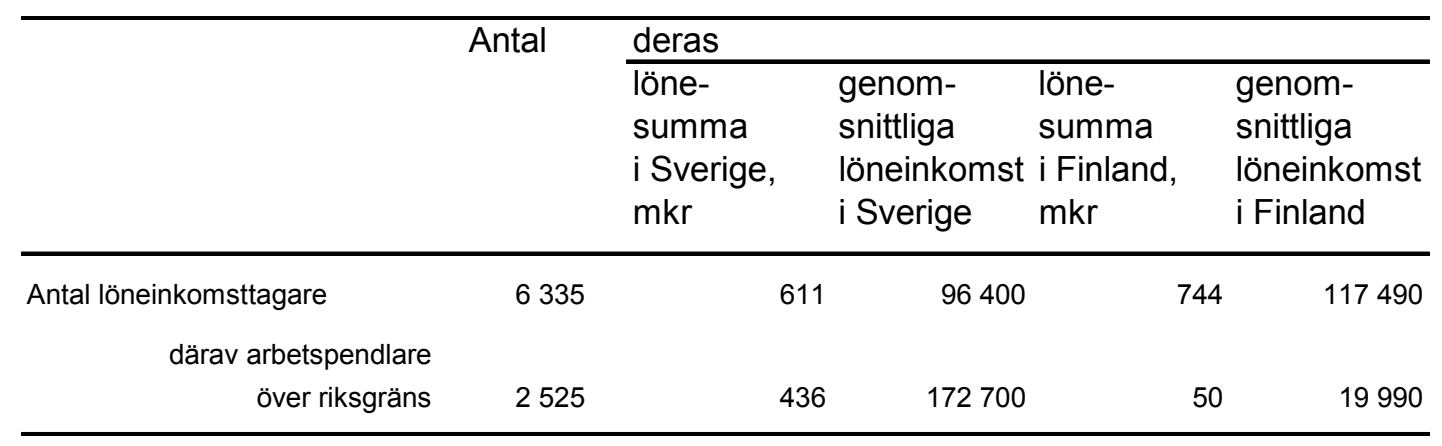

\subsection{Jämn fördelningen mellan könen}

Löneinkomsttagarna var relativt jämnt fördelade mellan dem som var under respektive över 35 år. Bland arbetspendlarna dominerade gruppen över 35 år något. 54 procent var 35 år och däröver och 46 procent var under 35 år. Könsfördelningen var relativt jämn. 52 procent av de finländska löneinkomsttagarna i Sverige var män och 48 procent kvinnor. Fördelningen mellan manliga respektive kvinnliga löneinkomsttagare var betydligt jämnare fördelad bland finländare med anknytning till den svenska arbetsmarknaden än för norrmän och danskar i Sverige. Se tabell 3 a. 
Om vi bryter ner statistiken i finare åldersgrupper och kön blir bilden följande. Den största åldersgruppen finländska löneinkomsttagare i Sverige var gruppen 25-34 år, vilken utgjorde nästan 25 procent av samtliga finländska löneinkomsttagare. Minst antal löneinkomsttagare fanns i den yngsta gruppen samt $i$ grupperna över 54 år. Noterbart är den stora gruppen unga finländska kvinnor i åldern 20-24 år som hade löneinkomster i Sverige. Den gruppen kvinnor var den största åldersgruppen av alla och bestod av 825 personer.

Tabell 3a. Personer folkbokförda i Finland med inkomster i Sverige efter ålder och kön år 2001

\begin{tabular}{|c|c|c|c|c|c|c|}
\hline \multirow[t]{2}{*}{ Âlder } & \multicolumn{2}{|c|}{ Löneinkomsttagare } & \multicolumn{4}{|c|}{ Arbetspendlare } \\
\hline & Män & Kvinnor & Totalt & Män & Kvinnor & Totalt \\
\hline $15-19$ & 156 & 290 & 446 & 44 & 65 & 109 \\
\hline $20-24$ & 449 & 825 & 1274 & 159 & 276 & 435 \\
\hline $25-34$ & 775 & 762 & 1537 & 310 & 299 & 609 \\
\hline $35-44$ & 689 & 492 & 1181 & 290 & 238 & 528 \\
\hline $45-54$ & 767 & 440 & 1207 & 350 & 201 & 551 \\
\hline $55-59$ & 271 & 135 & 406 & 127 & 61 & 188 \\
\hline $60+$ & 182 & 102 & 284 & 59 & 46 & 105 \\
\hline Summa & 3289 & 3046 & 6335 & 1339 & 1186 & 2525 \\
\hline
\end{tabular}

Medianlönesumman $^{1}$ för löneinkomsttagarna var ca 43000 SEK. Högst var den i åldersgruppen 35-44 år med något över 80000 SEK. Se tabell 3b. Kvinnorna hade högre medianlönesummor än männen i de yngsta åldersgrupperna.

För arbetspendlarna var medianlönesumman 148000 SEK. Den stora skillnaden i medianlön mellan löneinkomsttagare och arbetspendlare beror på att personen måste uppnå en viss inkomstnivå för att räknas som arbetspendlare och att löneinkomsten skall vara högre från arbetet i Sverige än från en eventuell löneinkomst i Finland.

För männen var medianlönesumman högst $\mathrm{i}$ åldersgruppen 55-59 år, 245000 SEK. För kvinnor var den högst i åldern 45-54 år med 197000 SEK.

\footnotetext{
${ }^{1}$ Medianlönesumman är den lönesumma som ligger i mitten när lönesummorna sorterats i storleksordning.
} 
Tabell 3b. Medianlönesumman år 2001 för inkomsttagare och arbetspendlare fördelade efter kön och ålder. SEK

\begin{tabular}{|c|c|c|c|c|c|c|}
\hline \multirow[t]{3}{*}{ Ålder } & \multicolumn{6}{|c|}{ Medianlönesumma } \\
\hline & \multicolumn{2}{|c|}{ Löneinkomsttagare } & \multicolumn{3}{|c|}{ Arbetspendlare } & \multirow[b]{2}{*}{ Totalt } \\
\hline & Män & Kvinnor & Totalt & Män & Kvinnor & \\
\hline $15-19$ & 13424 & 20035 & 17842 & 21632 & 24217 & 23105 \\
\hline $20-24$ & 33814 & 33831 & 33826 & 66872 & 47165 & 53402 \\
\hline $25-34$ & 74899 & 54730 & 63570 & 167375 & 135455 & 149284 \\
\hline $35-44$ & 78125 & 82727 & 81080 & 217617 & 190110 & 204185 \\
\hline $45-54$ & 67899 & 71226 & 70622 & 224960 & 196724 & 208260 \\
\hline $55-59$ & 87696 & 36904 & 63753 & 245000 & 185467 & 216864 \\
\hline $60+$ & 18426 & 34098 & 20777 & 161967 & 95500 & 118191 \\
\hline Summa & 52254 & 37898 & 43549 & 189893 & 114235 & 148443 \\
\hline
\end{tabular}

\subsection{Utbildning}

Utbildningsnivån är indelad $\mathrm{i}$ tre grupper förgymnasial, gymnasial och eftergymnasial utbildning samt gruppen okänd ${ }^{2}$. I finländska materialet kan man inte särskilja personer med okänd och förgymnasial utbildning. I tabell $4 \mathrm{a}$ och $\mathrm{b}$ redovisas därför personer med förgymnasial utbildning $\mathrm{i}$ gruppen Okänd. Den största gruppen för både arbetspendlare och inkomsttagare var personer med gymnasial utbildning. Gymnasial utbildning, var också den största gruppen för både manliga och kvinnliga inkomsttagare respektive arbetspendlare.

Tabell 4a. Antal inkomsttagare respektive arbetspendlare efter utbildningsnivå och kön år 2001.

\begin{tabular}{lrrrrrrr}
\hline Utbildning & \multicolumn{3}{c}{ Löneinkomsttagare } & \multicolumn{2}{c}{ Arbetspendlare } \\
& Män Kvinnor & Totalt & Män & Kvinnor & Totalt \\
\hline 1 Förgymnasial utb. & - & - & - & - & - & - \\
2 Gymnasial utb. högst 3 år & 1183 & 1341 & 2524 & 534 & 517 & 1051 \\
3 Eftergymnasial utb. Inkl. 4-årig gymnasial utb & 1139 & 1075 & 2214 & 330 & 407 & 737 \\
9 Okänd & 967 & 630 & 1597 & 475 & 262 & 737 \\
Summa & 3289 & 3046 & 6335 & 1339 & 1186 & 2525
\end{tabular}

\footnotetext{
${ }^{2}$ Indelningen bygger på ISCED 97.
} 
Medianlönesumman var högst i gruppen med eftergymnasial utbildning. För löneinkomsttagarna var den 51000 SEK och för arbetspendlarna 211 000 SEK. De manliga löneinkomsttagarna hade däremot högst lön i gruppen med gymnasial utbildning och lägst i gruppen med eftergymnasial utbildning. I övrigt var medianlönesumman högst i grupp tre, eftergymnasial utbildning.

Tabell 4b. Medianlönesumman i SEK för löneinkomsttagare och arbetspendlare efter utbildningsnivå år 2001

\begin{tabular}{|c|c|c|c|c|c|c|}
\hline \multirow[t]{3}{*}{ Utbildning } & \multicolumn{6}{|c|}{ Medianlönesumma } \\
\hline & \multicolumn{3}{|c|}{ Löneinkomsttagare } & \multicolumn{2}{|c|}{ Arbetspendlare } & \multirow[b]{2}{*}{ Totalt } \\
\hline & Män & Kvinnor & Totalt & Män & Kvinnor & \\
\hline 1 Förgymnasial utb. & - & - & - & - & - & - \\
\hline 2 Gymnasial utb. högst 3 år & 57701 & 35888 & 41758 & 164278 & 69561 & 107424 \\
\hline 3 Eftergymnasial utb. Inkl. 4-årig gymnasial utb & 40482 & 62276 & 51255 & 275003 & 180097 & 210985 \\
\hline 9 Okänd & 54810 & 27068 & 38300 & 144473 & 105580 & 134028 \\
\hline Summa & 52254 & 37898 & 43549 & 189893 & 114235 & 148443 \\
\hline
\end{tabular}

\subsection{Näringsgren ${ }^{3}$}

De klart största näringsgrenarna för både löneinkomsttagare och arbetspendlare var Hälso- och sjukvård, där majoriteten var kvinnor (ungefär 85 $\%$ ) och Transport och kommunikation, där majoriteten var män. Dominansen var däremot inte lika tydlig som inom hälso- och sjukvården. Tillsammans gav dessa två näringsgrenar löneinkomster till 40 procent av löneinkomsttagarna och 50 procent av arbetspendlarna.

Övriga näringsgrenar av betydelse var Tillverkning, Fastighets- och uthyrningsverksamhet och företagstjänster och Utbildning.

\footnotetext{
${ }^{3}$ Redovisning på näringsgren följer EU:s näringsgrensstandard NACE Rev 1. Redovisningen sker på ensiffrig nivå, vilken omfattar 17 avdelningar.
} 
Tabell 5a. Antal löneinkomsttagare och arbetspendlare efter näringsgren och kön år 2001

\begin{tabular}{|c|c|c|c|c|c|c|}
\hline \multirow[t]{2}{*}{ Näringsgren } & \multicolumn{2}{|c|}{ Löneinkomsttagare } & \multicolumn{4}{|c|}{ Arbetspendlare } \\
\hline & Män & Kvinnor & Totalt & Män & Kvinnor & talt \\
\hline Jordbruk, jakt och skogsbruk & 153 & 34 & 187 & 78 & 15 & 93 \\
\hline Fiske & 0 & 0 & 0 & 0 & 0 & 0 \\
\hline Utvinning & 22 & 3 & 25 & 14 & 0 & 14 \\
\hline Tillverkning & 505 & 133 & 638 & 224 & 51 & 275 \\
\hline El, -gas-, värme- och vattenförsörjning & 7 & 0 & 7 & 5 & 0 & 5 \\
\hline Byggverksamhet & 318 & 23 & 341 & 132 & 9 & 141 \\
\hline Partihandel och detaljhandel & 141 & 103 & 244 & 64 & 32 & 96 \\
\hline Hotell- och restaurantverksamhet & 58 & 144 & 202 & 22 & 49 & 71 \\
\hline Transport, magasinering och kommunikation & 702 & 467 & 1169 & 438 & 264 & 702 \\
\hline Finansiell verksamhet & 40 & 25 & 65 & 15 & 16 & 31 \\
\hline Fastighets- och uthyrningsverksamhet, företagstjänster & 442 & 403 & 845 & 126 & 128 & 254 \\
\hline Offentlig förvaltning och försvar & 122 & 75 & 197 & 23 & 24 & 47 \\
\hline Utbildning & 310 & 259 & 569 & 46 & 69 & 115 \\
\hline Hälso- och sjukvård, sociala tjänster, veterinärverksamhet & 231 & 1230 & 1461 & 86 & 493 & 579 \\
\hline Andra samhälleliga och personliga tjänster & 217 & 138 & 355 & 58 & 34 & 92 \\
\hline Förvärvsarbete i hushåll & 0 & 0 & 0 & 0 & 0 & 0 \\
\hline Verksamhet vid internationella organisationer, utländska ambassader & 0 & 0 & 0 & 0 & 0 & 0 \\
\hline Okänt & 21 & 9 & 30 & 8 & 2 & 10 \\
\hline Summa & 3289 & 3046 & 6335 & 1339 & 1186 & 2525 \\
\hline
\end{tabular}

Medianlönesumman varierade kraftigt mellan näringsgrenarna. För inkomsttagarna var medianlönesumman högst inom branscherna Transport m.m. och El-, gas-, värme- och vattenförsörjning. För arbetspendlarna var medianlönesumman klart högst inom Utvinning, men hänsyn bör tas till att den branschen endast sysselsatte 14 arbetspendlare.

För arbetspendlare var medianlönesumman även förhållandevis hög inom Transport och Utbildningen, vilka också sysselsatte förhållandevis många finländare.

Tabell 5b. Medianlönesumma år 2001 efter näringsgren fördelad efter kön. SEK

\begin{tabular}{|c|c|c|c|c|c|c|}
\hline \multirow[t]{2}{*}{ Näringsgren } & \multicolumn{3}{|c|}{$\begin{array}{l}\text { Medianlönesumma } \\
\text { Inkomsttagare }\end{array}$} & \multicolumn{3}{|c|}{ Arbetspendlare } \\
\hline & Män & Kvinnor & Totalt & Män & Kvinnor & Totalt \\
\hline Jordbruk, jakt och skogsbruk & 27986 & 10046 & 23061 & 78583 & 27120 & 66872 \\
\hline Fiske & 0 & 0 & 0 & 0 & 0 & 0 \\
\hline Utvinning & 161048 & 31036 & 75720 & 306566 & 0 & 306566 \\
\hline Tillverkning & 69736 & 50502 & 66194 & 163207 & 115428 & 158052 \\
\hline El, -gas-, värme- och vattenförsörjning & 100335 & 0 & 100335 & 192964 & 0 & 192964 \\
\hline Byggverksamhet & 53534 & 42168 & 52212 & 104705 & 67442 & 101812 \\
\hline Partihandel och detaljhandel & 77702 & 35925 & 58523 & 154596 & 135208 & 148915 \\
\hline Hotell- och restaurantverksamhet & 19780 & 18741 & 19515 & 50750 & 28782 & 35680 \\
\hline Transport, magasinering och kommunikation & 198277 & 112399 & 164535 & 234483 & 198625 & 217370 \\
\hline Finasiell verksamhet & 25000 & 75347 & 45600 & 67879 & 94492 & 75347 \\
\hline Fastighets- och uthyrningsverksamhet, företagstjänster & 21624 & 22680 & 22212 & 135962 & 84715 & 105623 \\
\hline Offentlig förvaltning och försvar & 7277 & 28800 & 14418 & 92746 & 176666 & 131720 \\
\hline Utbildning & 8000 & 11200 & 9000 & 141060 & 142759 & 142759 \\
\hline Hälso- och sjukvård, sociala tjänster, veterinärverksamhet & 61438 & 40587 & 42664 & 138049 & 88324 & 95456 \\
\hline Andra samhälleliga och personliga tjänster & 23694 & 16479 & 19150 & 132887 & 46210 & 86507 \\
\hline Förvärvsarbete i hushåll & 0 & 0 & 0 & 0 & 0 & 0 \\
\hline Verksamhet vid internat. organisationer, utl. ambassader & 0 & 0 & 0 & 0 & 0 & 0 \\
\hline Okänt & 47378 & 24828 & 27386 & 95413 & 62805 & 94239 \\
\hline Summa & 52254 & 37898 & 43549 & 189893 & 114235 & 148443 \\
\hline
\end{tabular}




\subsection{Sektor}

Redovisningen av sektor sker i två grupper nämligen Offentlig förvaltning och service samt Näringslivet inklusive offentliga bolag.

71 procent av inkomsttagarna och 79 procent av arbetspendlarna arbetade inom näringslivet. Männen fanns i större utsträckning än kvinnorna i näringslivet, 80 procent av de manliga löneinkomsttagarna och 90 procent av arbetspendlarna fick sina inkomster från näringslivet. För kvinnorna var jämförande siffror 62 respektive 66 procent.

Tabell 6a. Antal löneinkomsttagare och arbetspendlare efter sektor år 2001 fördelade efter kön.

\begin{tabular}{|c|c|c|c|c|c|c|}
\hline \multirow[t]{2}{*}{ Sektor } & \multicolumn{2}{|c|}{ Löneinkomsttagare } & \multicolumn{4}{|c|}{ Arbetspendlare } \\
\hline & Män & Kvinnor & Totalt & Män & Kvinnor & Totalt \\
\hline Offentlig förvaltning och service & 663 & 1163 & 1826 & 124 & 409 & 533 \\
\hline Näringslivet inkl. offentliga bolag & 2626 & 1883 & 4509 & 1215 & 777 & 1992 \\
\hline Summa & 3289 & 3046 & 6335 & 1339 & 1186 & 2525 \\
\hline
\end{tabular}

Medianlönesumman var också högre i näringslivet än i offentlig förvaltning. Enda undantaget var kvinnliga arbetspendlare, som tjänade mer i offentlig sektor än i näringslivet, 126 000S SEK jämfört med 106000 SEK.

Tabell 6b. Medianlön i SEK för löneinkomsttagare och arbetspendlare efter sektor år 2001

\begin{tabular}{lrrrrrrr}
\hline Sektor & \multicolumn{3}{c}{$\begin{array}{c}\text { Medianlönesumma } \\
\text { Löneinkomsttagare } \\
\end{array}$} & Män & Kvinnor & Totalt & \multicolumn{2}{c}{$\begin{array}{c}\text { Arbetspendlare } \\
\text { Män }\end{array}$} & Kvinnor & Totalt \\
\hline Offentlig förvaltning och service & 11000 & 35886 & 30000 & 179615 & 126211 & 135047 \\
Näringslivet inkl. offentliga bolag & 66149 & 39853 & 52252 & 190624 & 106376 & 152939 \\
Summa & 52254 & 37898 & 43549 & 189893 & 114235 & 148443 \\
\hline
\end{tabular}




\subsection{Födelseregion}

Löneinkomsttagarna respektive arbetspendlarnas födelseland har grupperats på tre regioner, Finland, Sverige och övriga.

En klar majoritet av de finländska löneinkomsttagarna respektive arbetspendlarna var födda i Finland, 88 procent respektive 87 procent.

Tabell 7a. Antal inkomsttagare och arbetspendlare efter födelseregion och kön

\begin{tabular}{lrrrrrr}
\hline Födelseregion & \multicolumn{2}{c}{$\begin{array}{c}\text { Löneinkomsttagare } \\
\text { Män }\end{array}$} & Kvinnor & Totalt & \multicolumn{3}{c}{ Arbetspendlare } \\
& 2834 & 2752 & 5586 & 1123 & 1084 & 2207 \\
\hline Finland & 2562 & 258 & 620 & 175 & 92 & 267 \\
Sverige & 93 & 36 & 129 & 41 & 10 & 51 \\
Övriga & 3289 & 3046 & 6335 & 1339 & 1186 & 2525 \\
Summa & & & & & &
\end{tabular}

Medianlönesummorna i Sverige var relativt lika mellan de tre grupperna. För inkomsttagarna var den högst för de personer som var födda i Finland, 44000 SEK, medan de för arbetspendlarna var den högst $i$ gruppen övriga världen, 158000 SEK.

Medianlönesumman för män och kvinnor fördelade sig lika över grupperna. För inkomsttagarna var det männen som var födda i Sverige och kvinnorna som var födda i Finland som hade den högsta medianlönen. För arbetspendlare var medianlönesumman högst för båda könen i gruppen som hade Finland som födelseregion.

Tabell 7b. Medianlönesumma i SEK för löneinkomsttagare och arbetspendlare efter födelseregion år 2001

\begin{tabular}{lcccrrr}
\hline Födelseregion & \multicolumn{2}{c}{$\begin{array}{c}\text { Medianlönesumma } \\
\text { Löneinkomsttagare }\end{array}$} & \multicolumn{3}{c}{ Arbetspendlare } \\
& Män & Kvinnor & Totalt & Män & Kvinnor & Totalt \\
\hline Finland & 51427 & 39276 & 43836 & 198448 & 116752 & 152736 \\
Sverige & 58254 & 27358 & 41605 & 134112 & 76042 & 115428 \\
Övriga & 40077 & 30842 & 35497 & 158421 & 94978 & 158009 \\
Summa & 52254 & 37898 & 43549 & 189893 & 114235 & 148443 \\
\hline
\end{tabular}




\subsection{Regional fördelning}

Den landgräns som förbinder Sverige och Finland ligger längst i norr och är glest befolkad. Kontaktytorna i gränsområdet är dock väl utbyggda, vilket kan belysas med att ungefär hälften av Haparandas befolkning är född i Finland. Haparanda ligger i direkt anslutning till finska Torneå. Kommunerna ligger på var sin sida om Torne älv. I övrigt avgränsas Sverige och Finland av relativt breda vatten som Bottenviken, Norra och Södra Kvarken samt Bottenhavet. Stockholm ligger relativt nära Åland och Åbo i Egentliga Finland. Helsingfors ligger i Finska viken långt från gränstrakterna till Sverige. De befolkningstäta delarna av Finland ligger framför allt i landets sydöstra del. På den svenska sidan är det framförallt Stockholm och Uppsala län som är tätbefolkade och som ligger nära det skärgårdshav som förbinder Sverige med finska Åland och Egentliga Finland.

\section{Löneinkomsttagare}

Antalet personer som var folkbokförda i Finland 2001 och som hade inkomster i Sverige under samma år var 6335 . Av dessa var 27 procent folkbokförda i Helsingforstrakten (Nyland) och 15 procent var folkbokförda i det nordligaste landskapet Lappland, som också är det landskap som landvägen gränsar till Sverige. Av 6335 löneinkomsttagare hade mer än hälften, 53 procent, inkomster från ett arbetsställe i Stockholms län. 17 procent eller 993 personer hade inkomster från Norrbotten, 61 procent av dessa hade dessutom inkomster från en gränskommun i Sverige (Haparanda, Övertorneå, Pajala och Kiruna). Förutom dessa två län hade relativt många finländare inkomster från Västra Götalands län, 525 st.

\section{Arbetspendlare}

Av de 6335 finländska inkomsttagarna i Sverige klassificerades 2525 personer som arbetspendlarna över riksgräns. 975 av dessa var folkbokförda i Lappland, varav Torneå stod för en övervägande del. Andelen arbetspendlare av totala antalet inkomsttagare i respektive region var dessutom högst i Lappland där nästan 60 procent av inkomsttagarna definierades som arbetspendlare över riksgräns. Andelen arbetspendlare var också hög på Åland, drygt 50 procent.

I Stockholms län fanns mer än 50 procent av samtliga 2525 arbetspendlare. Andelen arbetspendlare var däremot inte lika hög som i Norrbottens län, 58 procent i Norrbottens län jämfört med 41 procent i Stockholms län, se tabell 9. 
Tabell 8. Antal personer folkbokförda i Finland med löneinkomster i Sverige år 2001. Fördelade efter bostadskommun eller -landskap i Finland.

\begin{tabular}{lrrr}
\hline Bostadslandskap & $\begin{array}{r}\text { Antal } \\
\text { inkomst- } \\
\text { tagare }\end{array}$ & $\begin{array}{r}\text { därav } \\
\text { arbets- } \\
\text { pendlare }\end{array}$ & $\begin{array}{r}\text { Andel } \\
\text { arbets- } \\
\text { pendlare }\end{array}$ \\
\hline Torneå & 336 & 232 & 69,0 \\
Muonio & 17 & 11 & 64,7 \\
Enontekis & 19 & 10 & 52,6 \\
Kolari & 61 & 39 & 63,9 \\
Pello & 88 & 47 & 53,4 \\
Övertorneå & 127 & 87 & 68,5 \\
Övriga Lappland & 327 & 153 & 46,8 \\
Nyland & 1714 & 503 & 29,3 \\
Alland & 515 & 264 & 51,3 \\
Egentliga Finland & 811 & 356 & 43,9 \\
Övriga Finland & $2 \mathbf{3 2 0}$ & 823 & 35,5 \\
Totalt & $\mathbf{6 3 3 5}$ & $\mathbf{2 5 2 5}$ & $\mathbf{3 9 , 9}$ \\
\hline
\end{tabular}

Tabell 9. Antal personer folkbokförda i Finland med löneinkomster i Sverige år 2001. Fördelade efter arbetskommun eller -län i Sverige.

\begin{tabular}{lrrr}
\hline & $\begin{array}{r}\text { I } \\
\text { inkomst- } \\
\text { tagare }\end{array}$ & $\begin{array}{r}\text { därav } \\
\text { arbets- } \\
\text { pendlare }\end{array}$ & $\begin{array}{r}\text { Andel } \\
\text { arbets- } \\
\text { pendlare }\end{array}$ \\
\hline Haparanda & 331 & 231 & 69,8 \\
Pajala & 54 & 33 & 61,1 \\
Övertorneå & 152 & 97 & 63,8 \\
Kiruna & 71 & 46 & 64,8 \\
Övriga Norrbotten & 385 & 169 & 43,9 \\
Stockholms län & 3350 & 1384 & 41,3 \\
Västra Götalands län & 525 & 162 & 30,9 \\
Övriga Län & 1467 & 403 & 27,5 \\
Totalt & $\mathbf{6 3 3 5}$ & $\mathbf{2 5 2 5}$ & $\mathbf{3 9 , 9}$ \\
\hline
\end{tabular}




\subsection{Lönesummor}

2474 av de totalt 6335 finländare som hade inkomster från Sverige hade högre summerad inkomst i Finland än i Sverige. Andelen norrmän med inkomster i Sverige som hade högre summerad inkomst i bostadslandet var 57 procent, vilket är betydlig mer än andelen finländare, 39 procent.

I diagram 1 redovisas löneinkomsttagarnas lönesummor fördelade efter deciler, som baserats på inkomster från Sverige. De 10 procent av finländarna som tjänade mest i Sverige hade enligt staplarna i decil 10, inkomster i Sverige till en summa av 242 miljoner kronor och i Finland hade de 55 miljoner kronor, omräknat till svensk valuta. Lägst summerad lönesumma i bostadslandet hade personerna i decil 9, 24 miljoner SEK, och i decil 5, 50 miljoner SEK. De högsta summerade inkomsterna från bostadslandet återfanns inte helt oväntat i de lägsta decilerna 1 och 2 . I tre av tio grupper hade finländska inkomsttagare i Sverige högre summerade lönesumma i Sverige än i Finland. Störst var skillnaden i decil 10, där lönesumman i Sverige nästan var 5 gånger så stor som i Finland.

Diagram 1. Finländska löneinkomsttagares decillönesummor i Sverige och Finland år 2001. Miljoner SEK

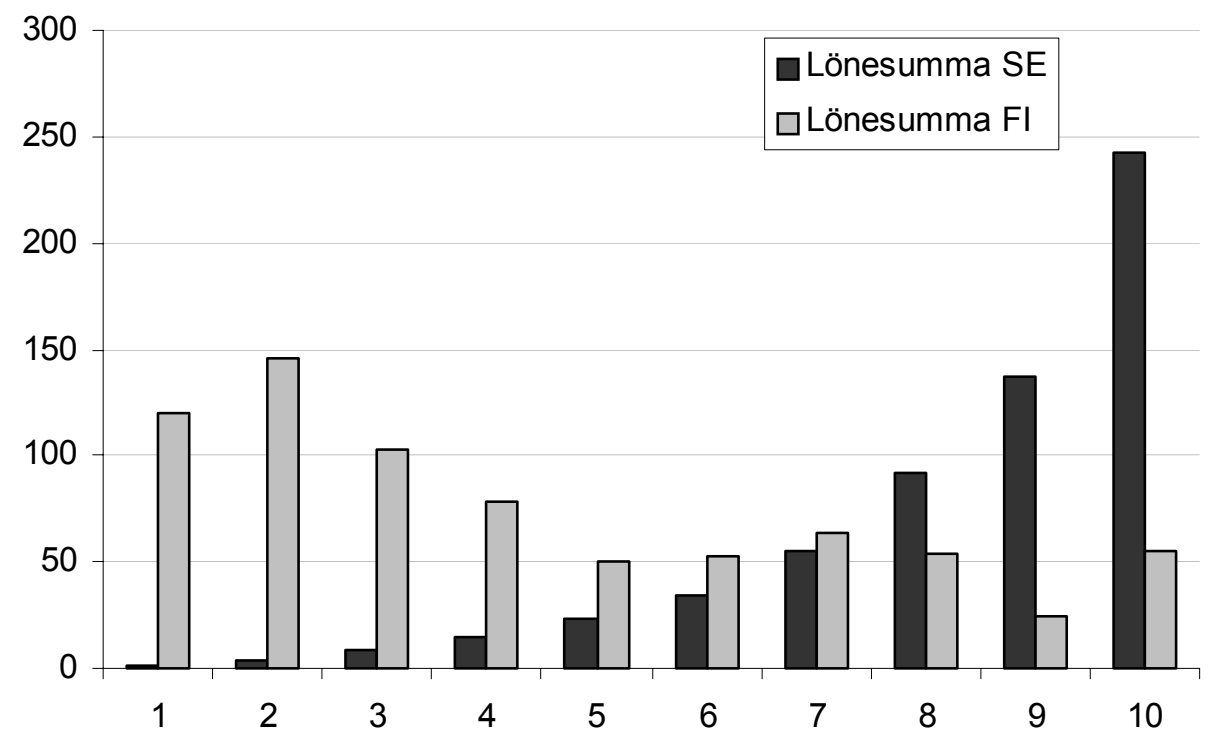




\section{Näringsgren}

Den högsta summerade lönesumman för både inkomsttagare och arbetspendlare över riksgräns återfanns inom transport och kommunikation, se tabell 10.

Tabell 10. Lönesummor fördelade på näringsgren år 2001. 1000-tal SEK

\begin{tabular}{|c|c|c|c|c|c|c|}
\hline \multirow{3}{*}{ Näringsgren } & \multicolumn{6}{|c|}{ Total lönesumma } \\
\hline & \multicolumn{3}{|c|}{ nkomstagare } & \multicolumn{3}{|c|}{ Arbetspendlare } \\
\hline & Män & Kvinnor & Totalt & Män & Kvinnor & Totalt \\
\hline Jordbruk, jakt och skogsbruk & 9148160 & 1512810 & 10660970 & 7447329 & 966332 & 8413661 \\
\hline Fiske & 0 & 0 & 0 & 0 & 0 & 0 \\
\hline Utvinning & 3935726 & 81166 & 4016892 & 3621451 & 0 & 3621451 \\
\hline Tillverkning & 66556857 & 11994005 & 78550862 & 44143915 & 7112014 & 51255929 \\
\hline El, -gas-, värme- och vattenförsörjning & 1169388 & 0 & 1169388 & 979036 & 0 & 979036 \\
\hline Byggverksamhet & 28305782 & 2383540 & 30689322 & 18502567 & 1893578 & 20396145 \\
\hline Partihandel och detaljhandel & 19685807 & 7700892 & 27386699 & 12458599 & 4352593 & 16811192 \\
\hline Hotell- och restaurantverksamhet & 2234545 & 4865612 & 7100157 & 1470162 & 2795955 & 4266117 \\
\hline Transport, magasinering och kommunikation & 126987011 & 57595661 & 184582672 & 106824469 & 46453297 & 153277766 \\
\hline Finasiell verksamhet & 6637105 & 2935074 & 9572179 & 5400955 & 2015812 & 7416767 \\
\hline Fastighets- och uthyrningsverksamhet, företagstjänster & 48606097 & 24787678 & 73393775 & 32992466 & 15528219 & 48520685 \\
\hline Offentlig förvaltning och försvar & 4957659 & 5103224 & 10060883 & 3475903 & 3683714 & 7159617 \\
\hline Utbildning & 14080117 & 14306429 & 28386546 & 7758184 & 10755222 & 18513406 \\
\hline Hälso- och sjukvård, soc. tjänster, veterinärverksamhet & 31678384 & 90506568 & 122184952 & 20821325 & 60590031 & 81411356 \\
\hline Andra samhälleliga och personliga tjänster & 15641463 & 4996898 & 20638361 & 9760305 & 2472741 & 12233046 \\
\hline Förvärvsarbete i hushåll & 0 & 0 & 0 & 0 & 0 & 0 \\
\hline Verksamhet vid int. organisationer, utl. ambassader & 0 & 0 & 0 & 0 & 0 & 0 \\
\hline Okänt & 1933826 & 362838 & 2296664 & 1550705 & 125609 & 1676314 \\
\hline Summa & 381557927 & 229132395 & 610690322 & 277207371 & 158745117 & 435952488 \\
\hline
\end{tabular}

De tre branscher som stod för den klart största delen av den totala lönesumman som utbetalats från arbetsställen i Sverige till personer folkbokförda i Finland var Transport och kommunikationer, Hälso- och sjukvård och Tillverkning, dessa utgjorde ungefär två tredje delar av den totala lönesumma. 
Tabell 11. Lönesummornas procentuella fördelning på kön och näringsgren år 2001

\begin{tabular}{|c|c|c|c|c|c|c|}
\hline \multirow[t]{2}{*}{ Näringsgren } & \multicolumn{3}{|c|}{$\begin{array}{l}\text { Andel av inkomsttagarnas } \\
\text { lönesumma i procent }\end{array}$} & \multicolumn{3}{|c|}{$\begin{array}{l}\text { Andel av arbetspendlarnas } \\
\text { lönesumma i procent } \\
\end{array}$} \\
\hline & Män & Kvinnor & Totalt & Män & Kvinnor & Totalt \\
\hline Jordbruk, jakt och skogsbruk & 1,5 & 0,2 & 1,7 & 1,7 & 0,2 & 1,9 \\
\hline Fiske & 0,0 & 0,0 & 0,0 & 0,0 & 0,0 & 0,0 \\
\hline Utvinning & 0,6 & 0,0 & 0,7 & 0,8 & 0,0 & 0,8 \\
\hline Tillverkning & 10,9 & 2,0 & 12,9 & 10,1 & 1,6 & 11,8 \\
\hline El, -gas-, värme- och vattenförsörjning & 0,2 & 0,0 & 0,2 & 0,2 & 0,0 & 0,2 \\
\hline Byggverksamhet & 4,6 & 0,4 & 5,0 & 4,2 & 0,4 & 4,7 \\
\hline Partihandel och detaljhandel & 3,2 & 1,3 & 4,5 & 2,9 & 1,0 & 3,9 \\
\hline Hotell- och restaurantverksamhet & 0,4 & 0,8 & 1,2 & 0,3 & 0,6 & 1,0 \\
\hline Transport, magasinering och kommunikation & 20,8 & 9,4 & 30,2 & 24,5 & 10,7 & 35,2 \\
\hline Finasiell verksamhet & 1,1 & 0,5 & 1,6 & 1,2 & 0,5 & 1,7 \\
\hline Fastighets- och uthyrningsverksamhet, företagstj & 8,0 & 4,1 & 12,0 & 7,6 & 3,6 & 11,1 \\
\hline Offentlig förvaltning och försvar & 0,8 & 0,8 & 1,6 & 0,8 & 0,8 & 1,6 \\
\hline Utbildning & 2,3 & 2,3 & 4,6 & 1,8 & 2,5 & 4,2 \\
\hline Hälso- och sjukvård, soc. tjänster, veterinärverks. & 5,2 & 14,8 & 20,0 & 4,8 & 13,9 & 18,7 \\
\hline Andra samhälleliga och personliga tjänster & 2,6 & 0,8 & 3,4 & 2,2 & 0,6 & 2,8 \\
\hline Förvärvsarbete i hushåll & 0,0 & 0,0 & 0,0 & 0,0 & 0,0 & 0,0 \\
\hline Verksamhet vid int. Org., utländska amb. & 0,0 & 0,0 & 0,0 & 0,0 & 0,0 & 0,0 \\
\hline Okänt & 0,3 & 0,1 & 0,4 & 0,4 & 0,0 & 0,4 \\
\hline Summa & 62,5 & 37,5 & 100 & 63,6 & 36,4 & 100 \\
\hline
\end{tabular}

Personer folkbokförda i Nylands landskap (inkluderar Helsingfors samt personer i tre av de fyra landskap som i tabell 8 kallas gränstrakter) tjänade klart mest, de stod för 71 procent av den totala lönesumman.

Arbetsställen från samtliga 21 län i Sverige betalade ut lönesummor till personer folkbokförda i Finland 2001. Högst summerad lönesumma betalades ut från arbetsställen i Stockholm, mer än 55 procent av den totala lönesumman, och nästan 20 procent betalades ut från Norrbotten. Lägst lönesumma betalades ut från Gotland och Blekinge. 
Tabell 12. Lönesumman år 2001 för finländska löneinkomsttagare med löneinkomst i Sverige fördelad efter Bostadslandskap i Finland och arbetslän i Sverige

\begin{tabular}{lrrlrr}
\hline Bostadslandskap & $\begin{array}{c}\text { Lönesumma } \\
\text { i SEK }\end{array}$ & i \% & Arbetslän & Lönesumma \\
& 169914441 & 27,8 & Stockholms län & i SEK & i \% \\
\hline Nyland & 80714429 & 13,2 & Uppsala län & 107055167 & 55,8 \\
Egentliga Finland & 13165152 & 2,2 & Södermanlands län & 3691279 & 0,6 \\
Satakunta & 3819028 & 0,6 & Östergötlands län & 9206073 & 1,5 \\
Egentliga Tavastland & 20285956 & 3,3 & Jönköpings län & 4870349 & 0,8 \\
Birkaland & 9393458 & 1,5 & Kronobergs län & 3246150 & 0,5 \\
Päijänne-Tavastland & 4825395 & 0,8 & Kalmar län & 1229228 & 0,2 \\
Kymmenedalen & 3716759 & 0,6 & Gotlands län & 1022717 & 0,2 \\
Södra Karelen & 3661369 & 0,6 & Blekinge län & 1463012 & 0,2 \\
Södra Savolax & 8186697 & 1,3 & Skåne län & 22207867 & 3,6 \\
Norra Savolax & 4324252 & 0,7 & Hallands län & 2544274 & 0,4 \\
Norra Karelen & 11388861 & 1,9 & Västra Götalands län & 41716543 & 6,8 \\
Mellersta Finland & 5297495 & 0,9 & Värmlands län & 3320677 & 0,5 \\
Södra Österbotten & 43975743 & 7,2 & Örebro län & 4487589 & 0,7 \\
Österbotten & 4610529 & 0,8 & Västmanlands län & 11002236 & 1,8 \\
Mellersta Österbotten & 23032624 & 3,8 & Dalarnas län & 3369572 & 0,6 \\
Norra Österbotten & 4900139 & 0,8 & Gävleborgs län & 8748385 & 1,4 \\
Kajanaland & 110676004 & 18,1 & Västernorrlands län & 6180680 & 1,0 \\
Lappland & 11428770 & 1,9 & Jämtlands län & 2272444 & 0,4 \\
Östra Nyland & 73373221 & 12,0 & Västerbottens län & 9956093 & 1,6 \\
Åland & & & Norrbottens län & 116523406 & 19,1 \\
& & & Okänt & 1952161 & 0,3 \\
Totalt & 610690322 & 100 & Totalt & 610690322 & 100 \\
\hline
\end{tabular}





\section{Rörlighet från Sverige till Finland}

I detta kapitel beskrivs pendlingsflödet från Sverige till Finland år 2001. Populationen omfattar de personer som i slutet av år 2001 stadigvarande bor i Sverige och som under år 2001 fătt löneinkomster från Finland. I rapporten och i tabellerna indelas personerna i två grupper: löneinkomsttagare och arbetspendlare. Dessa två begrepp har beskrivits mer ingående i stycke 1 och i bilaga 1 .

I slutet av år 2001 fanns det totalt 4206 personer, vilka bodde i Sverige och som under år 2001 haft löneinkomster i Finland. Se tabell 1. Av dessa definierades 1599 personer som arbetspendlare. De personer som bodde i Sverige fick totalt 44 miljoner euro i Finland och deras genomsnittliga löneinkomst var 10000 euro i Finland och 16000 euro i Sverige. De personer som fastställts som pendlare fick totalt 27 miljoner euro i löneinkomster från Finland. Deras genomsnittliga löneinkomst var 17000 euro i Finland och 200 euro i Sverige.

Tabell 13. Personer folkbokförda i Sverige med löneinkomster i Finland efter kön och ålder år 2001

\begin{tabular}{|c|c|c|c|c|c|}
\hline & \multirow[t]{2}{*}{ Antal } & \multicolumn{4}{|l|}{ deras } \\
\hline & & $\begin{array}{l}\text { löne- } \\
\text { summa } \\
\text { i Finland, } \\
\text { Euro }\end{array}$ & $\begin{array}{l}\text { genom- } \\
\text { snittliga } \\
\text { löneinkomst } \\
\text { i Finland }\end{array}$ & $\begin{array}{l}\text { löne- } \\
\text { summa } \\
\text { t i Sverige, } \\
\text { Euro }\end{array}$ & $\begin{array}{l}\text { genom- } \\
\text { snittliga } \\
\text { löneinkomst } \\
\text { i Sverige }\end{array}$ \\
\hline Antal löneinkomsttagare & 4206 & 44054802 & 10474 & 66486029 & 15807 \\
\hline $\begin{array}{r}\text { därav arbetspendlare } \\
\text { över riksgräns }\end{array}$ & 1599 & 26775283 & 16745 & 339546 & 212 \\
\hline
\end{tabular}

\section{1 Ålder}

Av personer med löneinkomster var 58 procent män och 42 procent kvinnor. Av pendlarna var 56 procent män och 44 procent kvinnor. Till sin åldersstruktur är de svenskar som arbetar i Finland unga. Drygt hälften av dem som fått löneinkomster var under 35 år. Av pendlarna hörde 58 procent till den här åldersgruppen. 
Tabell 14a. Personer folkbokförda i Sverige med inkomster i Finland efter kön och ålder år 2001

\begin{tabular}{|c|c|c|c|c|c|c|}
\hline & \multicolumn{3}{|c|}{ Löneinkomsttagare } & \multicolumn{3}{|c|}{ Arbetspendlare } \\
\hline & Totalt & Män & Kvinnor & Totalt & Män & Kvinnor \\
\hline Totalt & 4206 & 2460 & 1746 & 1599 & 897 & 702 \\
\hline $15-19$ & 209 & 77 & 132 & 129 & 48 & 81 \\
\hline $20-24$ & 852 & 354 & 498 & 444 & 172 & 272 \\
\hline $25-34$ & 1128 & 656 & 472 & 354 & 223 & 131 \\
\hline $35-44$ & 834 & 552 & 282 & 286 & 191 & 95 \\
\hline $45-54$ & 744 & 511 & 233 & 260 & 183 & 77 \\
\hline $55-59$ & 260 & 178 & 82 & 73 & 49 & 24 \\
\hline $60+$ & 179 & 132 & 47 & 53 & 31 & 22 \\
\hline
\end{tabular}

Det fanns fler män än kvinnor bland löneinkomsttagare och bland pendlare i alla åldersgrupper förutom bland de som var yngre än 25 år (diagram 2 och 3). Bland dem under 25 år var kvinnornas majoritet mycket dominerande. Åldersgruppen 20-24 år var den största för båda könen. Antalet kvinnor minskar, speciellt bland pendlarna, brant efter 25 år medan åldersgrupperna minskar långsammare bland männen och i de äldre åldersgrupperna är männens antal 2-3-tre gånger större.

Diagram 2. Personer folkbokförda i Sverige med löneinkomster i Finland efter kön och ålder år 2001

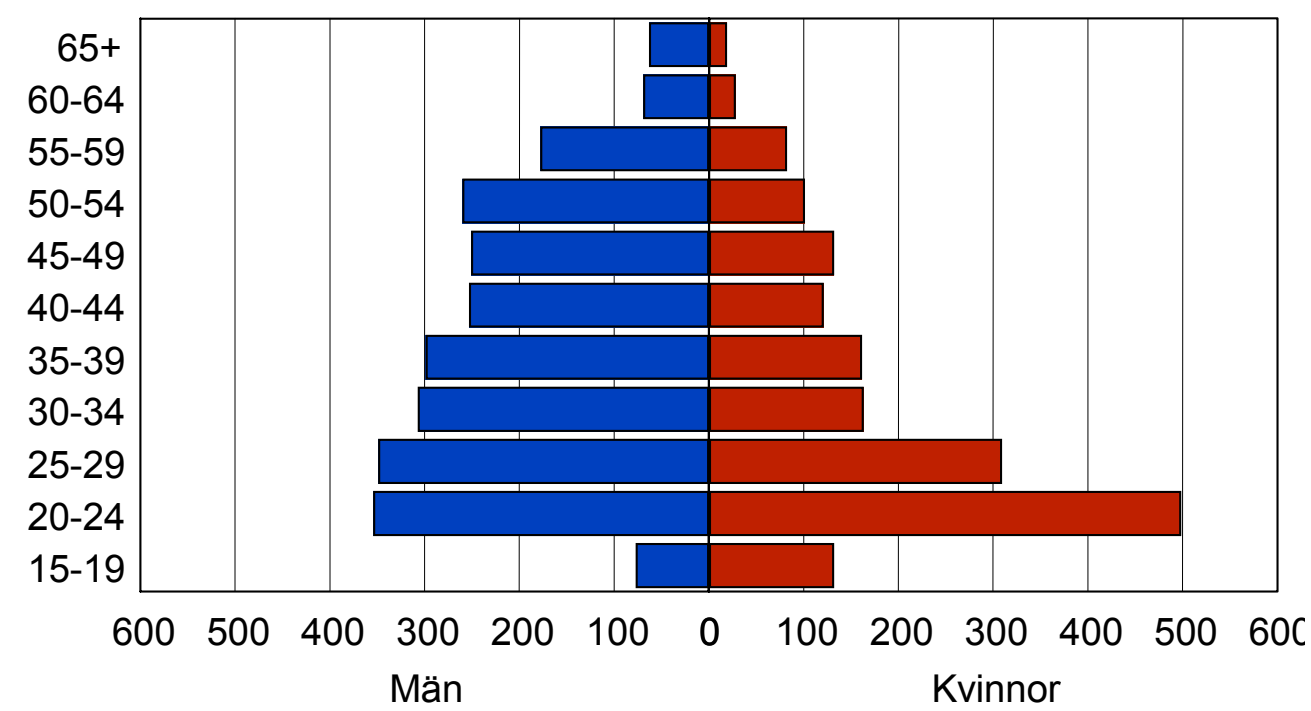


Diagram 3. Arbetspendlare efter kön och ålder 2001

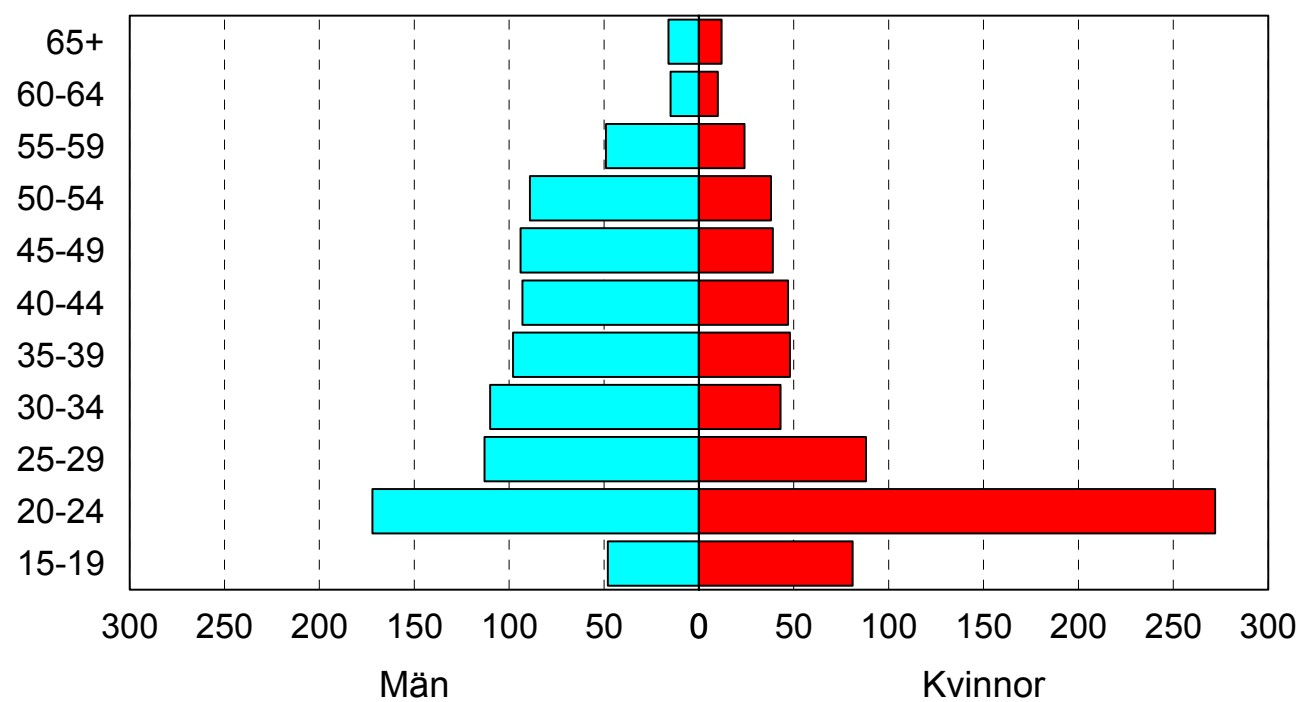

Medianinkomsterna för alla löneinkomsttagare var omkring 3500 och för pendlare omkring 6300 euro (tabell 14b). Medianinkomsterna var högst i åldersgruppen 35-44 både bland löneinkomsttagare (4 $500 €$ ) och pendlare $(18500 €)$.

Det fanns inte någon stor skillnad mellan männens och kvinnornas medianinkomster, skillnaden var bara omkring 700 euro. Bland pendlarna var männens medianinkomster däremot två och en halv gånger större än kvinnornas. Medianlöneinkomsterna för män som arbetade i Finland var 10800 och för kvinnor 4300 euro. Bland pendlarna var männens medianinkomster störst $i$ åldersgruppen 35-44 år (20 $700 €)$ och kvinnornas $i$ åldersgruppen 55-59 år (18 $500 €$ ). Visserligen fanns det bara 24 kvinnor i den här åldersgruppen.

Tabell 14b. Medianlönesumman år 2001 för löneinkomsttagare och arbetspendlare efter kön och ålder (euro)

\begin{tabular}{|c|c|c|c|c|c|c|}
\hline & \multicolumn{6}{|c|}{ Medianlönesumma } \\
\hline & \multicolumn{3}{|c|}{ Löneinkomsttagare } & \multicolumn{3}{|c|}{ Arbetspendlare } \\
\hline & Totalt & Män & Kvinnor & Totalt & Män & Kvinnor \\
\hline Totalt & 3466 & 3794 & 3114 & 6331 & 10764 & 4290 \\
\hline $15-19$ & 1680 & 1680 & 1667 & 2047 & 1823 & 2051 \\
\hline $20-24$ & 3291 & 3913 & 2944 & 3918 & 4593 & 3541 \\
\hline $25-34$ & 4289 & 4999 & 3654 & 8790 & 12561 & 6341 \\
\hline $35-44$ & 4510 & 4158 & 5045 & 18500 & 20724 & 14890 \\
\hline $45-54$ & 4359 & 4373 & 4212 & 17705 & 17678 & 17505 \\
\hline $55-59$ & 2145 & 2402 & 1710 & 17577 & 16431 & 18528 \\
\hline $60+$ & 1001 & 1170 & 763 & 1921 & 2000 & 1681 \\
\hline
\end{tabular}




\subsection{Utbildning}

Redovisningen av utbildningsnivå sker i klasserna 1-2 omfattande utbildning på grundnivå, klasserna 3-4 avser utbildning på gymnasienivå och kort högskoleutbildning och klasserna 5-6 omfattar eftergymnasial utbildning längre än två år och forskarutbildning. Dessutom ingår gruppen med okänd utbildning. Indelningen bygger på den internationella ISCED97-klassificeringen.

Omkring 67 procent av löneinkomsttagarna hade utbildning på minst mellannivå. Se tabell 15a. Ungefär en fjärdedel hade utbildning på mellannivå och 44 procent hade utbildning på högre nivå. Andelen personer med okänd utbildningsnivå var 23 procent. Detta torde tyda på att det i denna grupp finns många som kommer från andra länder och att det därför saknas uppgift om deras utbildningsbakgrund i det svenska utbildningsregistret. Av kvinnorna hade nästan hälften utbildning på högre nivå, medan bara 40 procent av männen hade det.

Av pendlarna hade 55 procent utbildning på minst mellannivå, 58 procent av kvinnorna och 53 procent av männen. Av kvinnorna hade 36 procent utbildning på högre nivå och 25 procent av männen. Andelen personer med okänd utbildning var större bland pendlarna än bland alla löneinkomsttagare. Okänd utbildning hade nästan en tredjedel av arbetspendlarna. I båda grupperna var kvinnornas utbildningsnivå något högre än männens. Jämförelsen försvåras dock av den stora andelen personer med okänd utbildning.

Tabell 15a. Antal löneinkomsttagare respektive arbetspendlare efter utbildningsnivå och kön år 2001

\begin{tabular}{lllllll}
\hline & \multicolumn{5}{c}{ Löneinkomsttagare } & \multicolumn{3}{c}{ Arbetspendlare } \\
\cline { 2 - 6 } & Totalt & Män & Kvinnor & Totalt & Män & Kvinnor \\
\hline Totalt & 4206 & 2460 & 1746 & 1599 & 897 & 702 \\
$\begin{array}{l}\text { Grundnivå } \\
\text { (ISCED 1-2) }\end{array}$ & 404 & 275 & 129 & 204 & 136 & 68 \\
$\begin{array}{l}\text { Mellannivå } \\
\text { (ISCED 3-4) }\end{array}$ & 1006 & 674 & 332 & 414 & 257 & 157 \\
$\begin{array}{l}\text { Högre nivå } \\
\text { (ISCED 5-6) }\end{array}$ & 1833 & 977 & 856 & 473 & 220 & 253 \\
Okänd & 963 & 534 & 429 & 508 & 284 & 224 \\
\hline
\end{tabular}

Medianinkomsten för löneinkomsttagare var störst $\mathrm{i}$ gruppen med okänd utbildningsnivå. När det gäller pendlare hade personer med utbildning på mellannivån de största medianinkomsterna. För kvinnornas del var medianinkomsterna också störst bland personer med okänd utbildningsnivå. Uppskattningen av utbildningsnivåns betydelse för inkomsterna försvåras av det stora antalet personer med okänd utbildningsnivå. 
Tabell 15b. Medianlönesumman år 2001 för löneinkomsttagare och arbetspendlare efter kön och utbildningsnivå (euro)

\begin{tabular}{lllllll}
\hline \multicolumn{7}{l}{ Medianlönesumma } \\
& \multicolumn{2}{l}{ Löneinkomsttagare } & \multicolumn{3}{l}{ Arbetspendlare } \\
& Totalt & Män & Kvinnor & Totalt & Män & Kvinnor \\
\hline Totalt & 3466 & 3794 & 3114 & 6331 & 10764 & 4290 \\
Grundnivå (ISCED 1-2) & 3340 & 4036 & 2328 & 6861 & 10091 & 3324 \\
Mellannivå (ISCED 3-4) & 3371 & 3700 & 2688 & 7825 & 12753 & 4143 \\
Högre nivå (ISCED 5-6) & 2478 & 2082 & 2772 & 5504 & 8345 & 4115 \\
Okänd & 5457 & 7798 & 4269 & 6521 & 10091 & 4783 \\
\hline
\end{tabular}

\subsection{Näring}

Största andelen löneinkomsttagare och pendlare i Finland arbetade inom servicesektorn. Av löneinkomsttagarna arbetade omkring 67 procent i servicebranscher och omkring 16 procent $\mathrm{i}$ industrin. Av pendlarna arbetade 61 procent inom servicesektorn och närmare en fjärdedel inom industrin. Skillnaden mellan män och kvinnor var tydlig. Männen arbetade i högre grad inom industrin än kvinnorna. Andelen manliga löneinkomsttagare inom industrin uppgick till 22 procent och för kvinnorna var andelen 9 procent. Bland arbetspendlarna var motsvarande andel 32 procent att jämföra med 13 procent för kvinnorna.

Bland löneinkomsttagarna var de största näringsgrenarna Utbildning med 12 procent och Tillverkning med 11 procent. Bland arbetspendlarna sysselsatte Tillverkningsindustrin flest personer med 16 procent. Handel, Hälso- och sjukvård samt Fastighets-, uthyrnings-, forsknings- och företagstjänster sysselsatte vardera ungefär 10 procent av arbetspendlarna. Den dominerande näringsgrenen för män var Tillverkning medan för kvinnorna var Hälso- och sjukvård den dominerande branschen. 
Tabell 16a. Antal löneinkomsttagare respektive arbetspendlare efter näringsgren och kön år 2001

\begin{tabular}{|c|c|c|c|c|c|c|}
\hline & \multicolumn{3}{|c|}{ Löneinkomsttagare } & \multicolumn{3}{|c|}{ Arbetspendlare } \\
\hline & Totalt & Män & Kvinnor & Totalt & Män & Kvinnor \\
\hline Totalt & 4206 & 2460 & 1746 & 1599 & 897 & 702 \\
\hline A Jordbruk, jakt och skogsbruk & 3 & 3 & - & 3 & 3 & - \\
\hline B Fiske & - & - & - & - & - & - \\
\hline C Utvinning & 6 & 2 & 4 & 2 & 1 & 1 \\
\hline D Tillverkning & 473 & 346 & 127 & 257 & 184 & 73 \\
\hline E El-, gas-, värme- och vattenförsörjning & 6 & 4 & 2 & 3 & 2 & 1 \\
\hline F Byggverksamhet & 201 & 184 & 17 & 117 & 103 & 14 \\
\hline G Parti- och detaljhandel & 330 & 182 & 148 & 153 & 78 & 75 \\
\hline $\mathrm{H}$ Hotell- och restaurangverksamhet & 235 & 150 & 85 & 69 & 28 & 41 \\
\hline I Transport, magasinering och kommunikation & 308 & 200 & 108 & 135 & 90 & 45 \\
\hline J Finansiell verksamhet & 55 & 32 & 23 & 22 & 10 & 12 \\
\hline K Fastighets- och uthyrn.verks., företagstjänster & 396 & 246 & 150 & 159 & 102 & 57 \\
\hline L Offentlig förvaltning och försvar & 267 & 131 & 136 & 88 & 39 & 49 \\
\hline M Utbildning & 504 & 307 & 197 & 116 & 54 & 62 \\
\hline N Hälso- och sjukvård, sociala tjänster & 359 & 80 & 279 & 145 & 30 & 115 \\
\hline O Andra samhälleliga och personliga tjänster & 357 & 212 & 145 & 94 & 42 & 52 \\
\hline P Förvärvsarbete i hushåll & - & - & - & - & - & - \\
\hline Q Verksamhet vid int.org. och utländska beskickn. & 2 & 2 & - & 1 & 1 & - \\
\hline X Okänd & 704 & 379 & 325 & 235 & 130 & 105 \\
\hline
\end{tabular}

Medianinkomsterna varierade i stor utsträckning mellan de olika näringsgrenarna. Se tabell 16b. När det gällde löneinkomsttagare varierade medianinkomsterna från 900 euro inom Hotell- och restaurangbranschen till närmare 11000 euro inom Tillverkning. Pendlarna hade de minsta medianinkomsterna inom Samhälleliga och Personliga tjänster, $3600 €$, och de största inom tillverkning, $17600 €$. Männen tjänade mest inom näringsgrenen Tillverkning, både bland löneinkomsttagare och pendlare. Av löneinkomsttagare hade kvinnorna åter de största medianinkomsterna inom finansiell verksamhet (5 $200 €$ ) och av pendlarna inom näringsgrenen utbildning, närmare 11000 euro. 
Tabell 16b. Medianlönesumman år 2001 för löneinkomsttagare och arbetspendlare efter näringsgren och kön (euro)

\begin{tabular}{|c|c|c|c|c|c|c|}
\hline & \multicolumn{3}{|c|}{ Löneinkomsttagare } & \multicolumn{3}{|c|}{ Arbetspendlare } \\
\hline & Totalt & Män & Kvinnor & Totalt & Män & Kvinnor \\
\hline Totalt & 3466 & 3794 & 3114 & 6331 & 10764 & 4290 \\
\hline A Jordbruk, jakt och skogsbruk & .. & .. & .. & .. & .. & .. \\
\hline B Fiske & .. & .. & .. & .. & .. & .. \\
\hline C Utvinning & 2344 & .. & .. & .. & .. & .. \\
\hline D Tillverkning & 10828 & 13808 & 4715 & 17578 & 24101 & 5387 \\
\hline E El-, gas-, värme- och vattenförsörjning & 2186 & 4426 & 308 & 4781 & 4781 & 308 \\
\hline F Byggverksamhet & 6861 & 7222 & 2298 & 9481 & 10764 & 2386 \\
\hline G Parti- och detaljhandel & 4819 & 6782 & 3304 & 5802 & 10349 & 3545 \\
\hline $\mathrm{H}$ Hotell- och restaurangverksamhet & 893 & 420 & 2596 & 3725 & 2498 & 4290 \\
\hline I Transport, magasinering och kommunikation & 4547 & 4816 & 3582 & 8079 & 12369 & 5089 \\
\hline J Finansiell verksamhet & 6501 & 8935 & 5246 & 6662 & 8935 & 5172 \\
\hline K Fastighets- och uthyrn.verks., företagstjänster & 5015 & 7556 & 3323 & 7082 & 10905 & 4129 \\
\hline L Offentlig förvaltning och försvar & 4433 & 4551 & 4271 & 6586 & 8703 & 4837 \\
\hline M Utbildning & 1099 & 630 & 2312 & 14330 & 19000 & 10965 \\
\hline N Hälso- och sjukvård, sociala tjänster & 3743 & 3794 & 3610 & 3610 & 3410 & 3610 \\
\hline O Andra samhälleliga och personliga tjänster & 1100 & 816 & 1499 & 2884 & 1947 & 2944 \\
\hline P Förvärvsarbete i hushåll & .. & .. & .. & .. & .. & .. \\
\hline $\begin{array}{l}\text { Q Verksamhet vid int.org. och utländska bes- } \\
\text { kickn. }\end{array}$ & .. &.. &.. &.. &.. & .. \\
\hline X Okänd & 1850 & 1880 & 1796 & 3967 & 5144 & 3246 \\
\hline
\end{tabular}

\subsection{Sektor}

Sektorindelningen återspeglar ägarskap och företagsform. I tabell $17 \mathrm{a}$ redovisas personerna efter om de arbetar i offentlig förvaltning och service eller inom näringslivet inkl. aktiebolag med statsägd aktiemajoritet.

Av både löneinkomsttagarna och pendlarna arbetade över 80 procent inom företagssektorn. Skillnaden mellan män och kvinnor var tydlig. Av kvinnorna arbetade 26-28 procent inom den offentliga sektorn, medan bara 10 procent av männen gjorde det. Detta förklaras naturligtvis av att kvinnorna arbetade inom hälso- och sjukvård och sociala tjänster.

Tabell 17a. Antal löneinkomsttagare respektive arbetspendlare efter sektor och kön år 2001

\begin{tabular}{lllllll}
\hline & \multicolumn{2}{l}{ Löneinkomsttagare } & \multicolumn{3}{c}{ Arbetspendlare } \\
& Totalt & Män & Kvinnor & Totalt & Män & Kvinnor \\
\hline Totalt & 4206 & 2460 & 1746 & 1599 & 897 & 702 \\
Offentlig förvaltning och service & 701 & 246 & 455 & 283 & 86 & 197 \\
Näringslivet inkl. offentliga bolag & 3505 & 2214 & 1291 & 1316 & 811 & 505 \\
\hline
\end{tabular}

Av samtliga löneinkomsttagare tjänade de som arbetade inom den offentliga sektorn mest både bland män och kvinnor. Medianinkomsten var 
omkring 4100 euro (tabell 17b). Av pendlarna tjänade däremot männen inom den privata sektorn nästan dubbelt så mycket än inom den offentliga sektorn. Kvinnornas medianlöneinkomster var däremot större inom den offentliga sektorn än i den privata sektorn.

Tabell 17b. Medianlönesumman år 2001 för löneinkomsttagare och arbetspendlare efter sektor och kön (euro)

\begin{tabular}{|c|c|c|c|c|c|c|}
\hline & \multicolumn{3}{|c|}{ Löneinkomsttagare } & \multicolumn{3}{|c|}{ Arbetspendlare } \\
\hline & Totalt & Män & Kvinnor & Totalt & Män & Kvinnor \\
\hline Totalt & 3466 & 3794 & 3114 & 6331 & 10764 & 4290 \\
\hline Offentlig förvaltning och service & 4144 & 4077 & 4144 & 5383 & 6566 & 5144 \\
\hline Näringslivet inkl. offentliga bolag & 3279 & 3753 & 2792 & 6555 & 11738 & 3993 \\
\hline
\end{tabular}

\subsection{Födelseregion}

Största delen av både löneinkomsttagarna och pendlarna var födda i Finland, se tabell 18a. 63 procent av löneinkomsttagarna och 81 procent av pendlarna var födda i Finland. I vardera gruppen var en större del av kvinnorna födda i Finland. Av alla löneinkomsttagare var 33 procent födda i Finland och av pendlarna 16 procent. Endast några få procent var födda utanför Finland eller Sverige.

Tabell 18a. Antal löneinkomsttagare och arbetspendlare efter födelseregion och kön

\begin{tabular}{lllllll}
\hline & \multicolumn{2}{l}{ Löneinkomsttagare } & \multicolumn{3}{c}{ Arbetspendlare } \\
& Totalt & Män & Kvinnor & Totalt & Män & Kvinnor \\
\hline Totalt & 4206 & 2460 & 1746 & 1599 & 897 & 702 \\
Finland & 2651 & 1367 & 1284 & 1290 & 700 & 590 \\
Sverige & 1366 & 961 & 405 & 252 & 158 & 94 \\
Övriga & 189 & 132 & 57 & 57 & 39 & 18 \\
\hline
\end{tabular}

Medianinkomsterna var i alla grupper störst för personer födda i Finland (tabell 18b). Skillnaden var tydligast bland pendlande män. Medianinkomsterna för män födda i Finland var 13000 euro, för män födda i Sverige 4200 euro och 4900 euro för personer födda någon annanstans.

Tabell 18b. Medianlönesumman år 2001 för löneinkomsttagare och arbetspendlare efter födelseregion och kön (euro)

\begin{tabular}{lllllll}
\hline & \multicolumn{5}{c}{ Löneinkomsttagare } & \multicolumn{3}{l}{ Arbetspendlare } \\
\cline { 2 - 6 } & Totalt & Män & Kvinnor & Totalt & Män & Kvinnor \\
\hline Totalt & 3466 & 3794 & 3114 & 6331 & 10764 & 4290 \\
Sverige & 1279 & 1208 & 1345 & 3444 & 4230 & 2281 \\
Finland & 4973 & 7243 & 3835 & 7067 & 13033 & 4596 \\
Övriga & 1946 & 2267 & 1173 & 4227 & 4947 & 3971 \\
\hline
\end{tabular}




\subsection{Regionala indelningar}

I slutet av år 2001 fanns det totalt 4206 personer som bodde i Sverige och som under året erhållit löneinkomst i Finland. Omkring 60 procent var bosatta i något av de s.k. gränslänen, dvs. Stockholms, Norrbottens eller Västerbottens län (tabell 19). Flest personer var folkbokförda i Stockholms län (1 649 personer). Näst flest personer kom från Norrbottens län (659), därefter Västra Götalands län (366), Uppsala län (322) och Skåne län (228). Det norra gränslänet, Västerbotten, var först sjätte län $i$ ordningen med 182 löneinkomsttagare. Av alla löneinkomsttagare definierades 1599 som pendlare. Deras regionala fördelning liknade den för löneinkomsttagarna.

I båda grupperna fanns det överraskande många personer som kom från län som varken genom land- eller vattenområde gränsar till Finland. Dessa var främst Västra Götaland och Skåne men också Östergötland.

Tabell 19. Personer folkbokförda i Sverige och som hade löneinkomst i Finland år 2001 fördelade efter bostadslän

\begin{tabular}{lllllll}
\hline & \multicolumn{3}{l}{ Löneinkomsttagare } & \multicolumn{2}{c}{ Arbetspendlare } \\
& Totalt & Män & Kvinnor & Totalt & Män & Kvinnor \\
\hline & & & & & & \\
Totalt & 4206 & 2460 & 1746 & 1599 & 897 & 702 \\
Stockholms län & 1649 & 945 & 704 & 468 & 275 & 193 \\
Norrbottens län & 659 & 423 & 236 & 423 & 274 & 149 \\
Västerbottens län & 182 & 91 & 91 & 72 & 27 & 45 \\
Summa gränstrakter & 2490 & 1459 & 1031 & 963 & 576 & 387 \\
& & & & & & \\
Västra Götalands län & 366 & 213 & 153 & 134 & 78 & 56 \\
Uppsala län & 322 & 177 & 145 & 124 & 48 & 76 \\
Skåne län & 228 & 137 & 91 & 100 & 49 & 51 \\
Östergötlands län & 127 & 73 & 54 & 49 & 20 & 29 \\
& & & & & & 126 \\
Övriga län & 673 & 401 & 272 & 229 & & 103 \\
\hline
\end{tabular}

Nästan en fjärdedel av alla löneinkomsttagare, dvs. omkring tusen personer, hade sin löneinkomst från arbetsplatser i Södra Österbotten. Därefter kom Nyland med 20 procent, Åland med 13 procent och Lappland med 10 procent.

Bland pendlarna låg samma landskap i topp i någon annan ordning. Största andelen eller 22 procent arbetade i Nyland, därefter kom Lappland med 19 procent samt Södra 
Tabell 20. Personer folkbokförda i Sverige med löneinkomst i Finland år 2001 fördelade efter arbetslandskap

\begin{tabular}{|c|c|c|c|c|c|c|}
\hline & \multicolumn{3}{|c|}{ Löneinkomsttagare } & \multicolumn{3}{|c|}{ Arbetspendlare } \\
\hline & Totalt & Män & Kvinnor & Totalt & Män & Kvinnor \\
\hline Totalt & 4206 & 2460 & 1746 & 1599 & 897 & 702 \\
\hline Södra Österbotten & 1007 & 628 & 379 & 195 & 114 & 81 \\
\hline Nyland & 841 & 456 & 385 & 353 & 188 & 165 \\
\hline Åland & 545 & 332 & 213 & 188 & 92 & 96 \\
\hline Lappland & 408 & 252 & 156 & 302 & 187 & 115 \\
\hline Österbotten & 273 & 124 & 149 & 94 & 40 & 54 \\
\hline Egentliga Finland & 176 & 97 & 79 & 65 & 37 & 28 \\
\hline Norra Österbotten & 117 & 74 & 43 & 52 & 29 & 23 \\
\hline Birkaland & 104 & 69 & 35 & 45 & 28 & 17 \\
\hline Övriga landskap & 318 & 195 & 123 & 122 & 79 & 43 \\
\hline Okänd & 417 & 233 & 184 & 183 & 103 & 80 \\
\hline
\end{tabular}

\subsection{Lönesummor}

I figur 3 redovisas alla löneinkomsttagare indelade i deciler på basis av de löner som förtjänats i Finland. De 10 procent av svenskarna som tjänade mest i Finland hade, enligt staplarna i decil 10, inkomster i Finland till en summa av 24 miljoner euro och i Sverige hade de 8 miljoner euro. Lägst summerad lönesumma i bostadslandet hade personerna i decil $9-3,5$ miljoner euro, och i decil 6 - 3,7 miljoner euro. De högsta summerade inkomsterna från bostadslandet återfanns inte helt oväntat i de lägsta decilerna 1 och 2 men också i decil 10. I två av tio grupper hade svenska inkomsttagare högre summerad lönesumma i Finland än i Sverige. Störst var skillnaden i decil 10, där lönesumman i Finland var nästan tre gånger så stor som i Sverige.

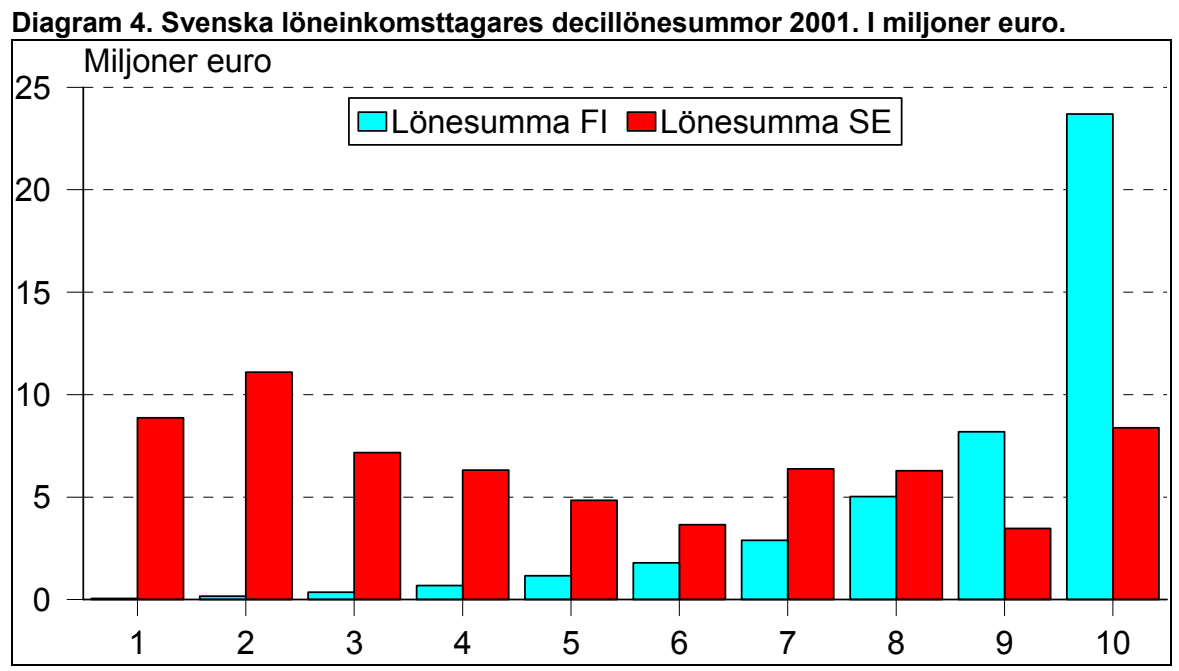


De löneinkomsttagare som i slutet av år 2001 bodde i Sverige och som samma år erhållit löneinkomst i Finland tjänade omkring 44 miljoner euro i Finland enligt skattemyndigheternas årsanmälningsuppgifter. Av denna lönesumma tjänade personer som definierats som pendlare nästan 60 procent, dvs. 26 miljoner euro (tabell 13, sidan 26). Av hela lönesumman tjänades nästan tre fjärde delar av män (tabell 21). Fördelat efter näringsgren tjänade män som arbetade inom Tillverkning den största andelen av lönesumman. Sett till lönesumman var följande näringsgrenar mest betydande nämligen Fastighets-, uthyrningsverksamhet m.m. företagstjänster, Handel samt Transport och kommunikation.

När det gäller pendlare var fördelningen efter näringsgren liknande, även om Tillverkningens andel av hela lönesumman var ännu större, den uppgick till drygt en tredjedel ab den totala lönesumman. Fördelat efter lönesumman var kvinnornas mest betydande näringsgrenar Hälso- och sjukvård och sociala tjänster samt Utbildning. Kvinnornas lönesummor från dessa näringsgrenar var dock mindre än 10 procent av den totala lönesumman både vad gäller löneinkomsttagare och pendlare. Kvinnorna hade större löneinkomster än männen endast inom Hälso- och sjukvård och sociala tjänster) samt Hotell- och restaurangverksamhet.

Tabell 21. Lönesummornas procentuella fördelning på kön och näringsgren år 2001

\begin{tabular}{|c|c|c|c|c|c|c|}
\hline & \multicolumn{3}{|c|}{ Löneinkomsttagare } & \multicolumn{3}{|c|}{ Arbetspendlare } \\
\hline & Totalt & Män & Kvinnor & Totalt & Män & Kvinnor \\
\hline Totalt & 100,0 & 73,2 & 26,8 & 100,0 & 76,1 & 23,9 \\
\hline A Jordbruk, jakt och skogsbruk & .. & .. & .. & .. & .. & .. \\
\hline B Fiske & 0,0 & 0,0 & 0,0 & 0,0 & 0,0 & 0,0 \\
\hline C Utvinning & 0,1 & 0,1 & 0,0 & 0,2 & 0,2 & 0,0 \\
\hline D Tillverkning & 27,7 & 25,0 & 2,7 & 36,1 & 33,0 & 3,2 \\
\hline E El-, gas-, värme- och vattenförsörjning & 0,0 & .. & .. & .. & .. & .. \\
\hline F Byggverksamhet & 5,7 & 5,5 & 0,2 & 5,9 & 5,6 & 0,3 \\
\hline G Parti- och detaljhandel & 8,2 & 6,4 & 1,9 & 8,7 & 6,8 & 1,9 \\
\hline $\mathrm{H}$ Hotell- och restaurangverksamhet & 1,8 & 0,9 & 0,9 & 1,7 & 0,7 & 1,0 \\
\hline I Transport, magasinering och kommunikation & 8,4 & 6,3 & 2,0 & 7,7 & 5,7 & 1,9 \\
\hline J Finansiell verksamhet & 2,1 & 1,5 & 0,5 & 1,3 & 0,9 & 0,4 \\
\hline K Fastighets- och uthyrn.verks., företagstjänster & 11,1 & 8,3 & 2,8 & 8,4 & 6,3 & 2,1 \\
\hline L Offentlig förvaltning och försvar & 5,6 & 3,0 & 2,6 & 5,2 & 3,0 & 2,2 \\
\hline M Utbildning & 8,1 & 4,3 & 3,8 & 8,2 & 4,3 & 3,9 \\
\hline N Hälso- och sjukvård, sociala tjänster & 6,8 & 2,0 & 4,7 & 5,1 & 1,5 & 3,6 \\
\hline O Andra samhälleliga och personliga tjänster & 4,2 & 2,9 & 1,3 & 2,5 & 1,4 & 1,1 \\
\hline P Förvärvsarbete i hushåll & 0,0 & 0,0 & 0,0 & 0,0 & 0,0 & 0,0 \\
\hline Q Verksamhet vid int.org. och utländska beskickn. & .. & .. & .. & .. & .. & .. \\
\hline X Okänd & 10,0 & 6,7 & 3,3 & 8,9 & 6,6 & 2,3 \\
\hline
\end{tabular}

Både när det gäller antal individer och lönesumma var Tillverkningsindustrin den mest betydande näringsgrenen. Se diagram $5 \mathrm{a}-\mathrm{b}$. Ser man till antalet löneinkomsttagare och storleken på lönesumman hade tillverkningsindustrin en mycket stor betydelse jämfört med de övriga närings- 
grenarna. Av samtliga personer arbetade 11 procent av alla löneinkomsttagare och 16 procent av pendlarna inom tillverkningen. 27 procent av löneinkomsttagarnas och 36 procent av pendlarnas lönesumma betalades ut inom Tillverkningsindustrin.

Diagram 5a. Antal löneinkomsttagare och lönesuma efter näringsgren (i \%). Ár 2001 Alla löneinkomsttagare

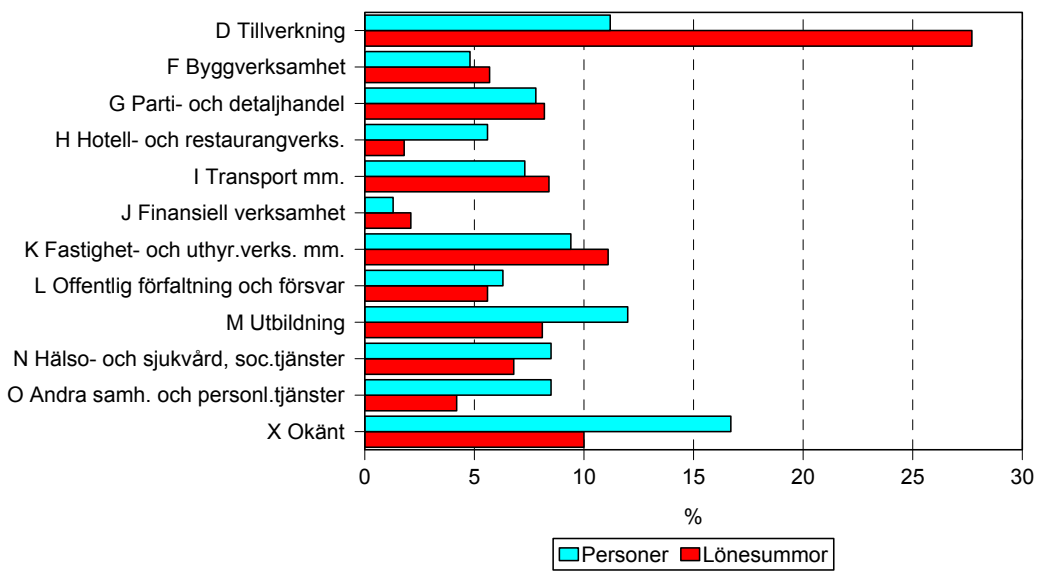

Diagram 5b. Antal arbetspendlare och lönesumma efter näringsgren (i \%). Âr 2001

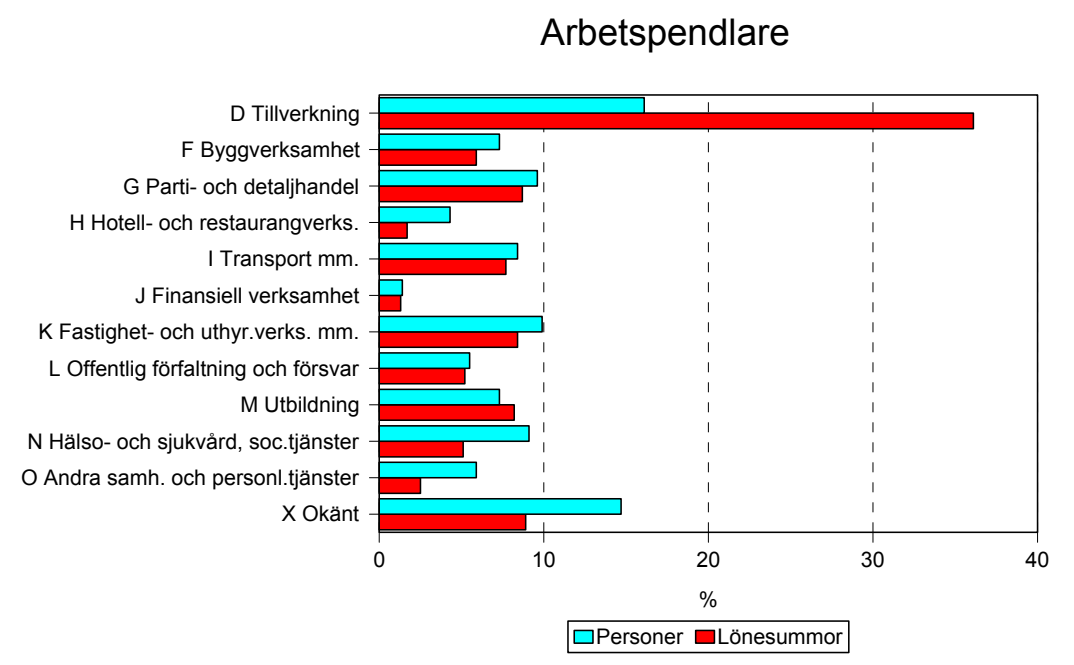

Fördelat efter bostadsregion hade Stockholms län den största andelen av den totala lönesumman, dvs. 37 procent. Se tabell 22. Därefter följer Norrbottens län med 22 procent, Östergötlands län med 12 och Västra Götalands län med 7 procent. Fördelat efter arbetsställeregion i Finland var lönesumman störst i Nylands landskap med 38 procent. Därefter kom Lappland med $17 \%$, Södra Österbotten med 13 och Åland med 6 procent. 75 procent av lönesumman intjänades i dessa fyra landskap. 
Tabell 22. Lönesumman för svenska löneinkomsttagare med löneinkomst i Finland efter bostadslän i Sverige och arbetslandskap i Finland. Âr 2001

\begin{tabular}{|c|c|c|c|c|c|}
\hline \multirow[t]{2}{*}{ Bostadslän } & \multicolumn{2}{|l|}{ Lönesumma } & \multirow[t]{2}{*}{ Arbetslandskap } & \multicolumn{2}{|l|}{ Lönesumma } \\
\hline & i Euro & $\%$ & & i Euro & $\%$ \\
\hline Totalt & 44054802 & 100,0 & Totalt & 44054802 & 100,0 \\
\hline Stockholms län & 16304640 & 37,0 & Nyland & 16743709 & 38,0 \\
\hline Uppsala län & 1940325 & 4,4 & Egentliga Finland & 1467400 & 3,3 \\
\hline Södermanlands län & 660445 & 1,5 & Satakunta & 320641 & 0,7 \\
\hline Östergötlands län & 5095476 & 11,6 & Egentliga Tavastland & 128840 & 0,3 \\
\hline Jönköpings län & 733693 & 1,7 & Birkaland & 1182611 & 2,7 \\
\hline Kronobergs län & 134573 & 0,3 & Päijät-Häme & 307027 & 0,7 \\
\hline Kalmar län & 225568 & 0,5 & Kymmenedalen & 108583 & 0,2 \\
\hline Gotlands län & 66070 & 0,1 & Södra Karelen & 264406 & 0,6 \\
\hline Blekinge län & 83385 & 0,2 & Södra Savolax & 122104 & 0,3 \\
\hline Skåne län & 1836050 & 4,2 & Norra Savolax & 307906 & 0,7 \\
\hline Hallands län & 222413 & 0,5 & Norra Karelen & 209833 & 0,5 \\
\hline Västra Götalands län & 3093173 & 7,0 & Mellersta Finland & 414862 & 0,9 \\
\hline Värmlands län & 406600 & 0,9 & Södra Österbotten & 5647271 & 12,8 \\
\hline Örebro län & 458192 & 1,0 & Österbotten & 1601466 & 3,6 \\
\hline Västmanlands län & 588509 & 1,3 & Mellersta Österbotten & 165761 & 0,4 \\
\hline Dalarnas län & 636435 & 1,4 & Norra Österbotten & 958958 & 2,2 \\
\hline Gävleborgs län & 412946 & 0,9 & Kajanaland & 11868 & 0,0 \\
\hline Västernorrlands län & 470218 & 1,1 & Lappland & 7550027 & 17,1 \\
\hline Jämtlands län & 195003 & 0,4 & Östra Nyland & 351349 & 0,8 \\
\hline Västerbottens län & 844550 & 1,9 & Åland & 2536715 & 5,8 \\
\hline Norrbottens län & 9646538 & 21,9 & Okänd & 3653465 & 8,3 \\
\hline
\end{tabular}





\section{Att studera ytterligare}

Utveckling över tiden:

Den redovisning som ingår i projektet Nordisk pendlingskarta avser förhållanden under år 2001. Därför ger resultaten endast en uppfattning av nivåerna på de företeelser som redovisas. Med uppgifter från flera år är det möjligt att följa vad arbetsmarknadskonjunkturer betyder, gränshinders betydelse o.s.v.

\section{Redovisning på karta}

- Andel av förvärvsarbetande per kommun.

- Varifrån kom de som hade löneinkomst i arbetslandet, antalsmässigt

\section{Arbetspendlare över riksgräns}

Vad har gränspendlarna för sysselsättningsstatus i befintlig sysselsättningsstatistik.

\section{Flyttare}

- Hur många arbetspendlare över riksgräns hade flyttat året före/året efter

- Flyttar man till arbete i samma bransch eller byter man bransch med flyttningen

- Flyttar man från arbetslöshet till sysselsättning.

Tidig indikator på omfattning av gränsöverskridande verksamhet

Det finns troligen möjligheter att redovisa preliminära data om antal löneinkomsttagare/löntagare före det slutliga fastställandet av statistiken. 



\section{Bilaga 1. Metodbeskrivning}

I Sverige, Danmark, Norge och Finland finns en registerbaserad sysselsättningsstatistik som är likartat uppbyggd och kan användas för att beskriva integrationen på den nordiska arbetsmarknaden. Metoden utgår från personer som finns registrerade med inkomst $i$ arbetslandet men som saknas i centrala personregister. Dessa personer har anställning i arbetslandet och är inte folkbokförda i landet i fråga. Genom att utbyta uppgifter om dessa personer mellan två länder är det möjligt att identifiera personernas bostadsland. Resultatet blir en grupp människor som bor i ett land och har löneinkomst $\mathrm{i}$ ett annat. Från denna grupp kan man därefter utifrån särskilda kriterier avskilja personer som betraktas som arbetspendlare över riksgräns.

Metodmässigt finns en brist i statistiken då vi utgår från personernas bostadsland vid slutet av året och inte tar hänsyn till att flyttning kan ha skett mellan Sverige och Finland tidigare under året. Detta kan ge en överskattning av antalet arbetspendlare. Det innebär också att en del av lönesumman kan vara utbetald när personen fortfarande bodde i samma land som lönen intjänats.

Det finns flera syften med att belysa antalet personer som arbetar i ett land och bor i ett annat:

- Mått på integrationen mellan länderna

- Rörligheten på nordisk arbetsmarknad

- Flödet av arbetsinkomster mellan länderna

- Förbättra den nationella sysselsättningsstatistiken. De personer som arbetar i ett land och bor i ett annat kommer inte med i arbetslandets statistik och redovisas som ej förvärvsarbetande i bostadslandets statistik.

- Fördjupa jämförelserna mellan de nordiska ländernas arbetsmarknader (benchmarking)

\section{Personnummer och matchning}

De nordiska länderna har väl utbyggda administrativa system för bl.a. folkbokföring och taxering. I dessa system identifieras personer med unika personnummer. Numren är olika konstruerade i de olika länderna, varför det inte utan vidare går att matcha på personnummer mellan ländernas register. Däremot finns uppgifter om födelsedatum, kön och namn registrerade i registren. Genom att kombinera dessa uppgifter är det möjligt att göra jämförelser mellan de uppgifter som finns om de aktuella 
personerna i båda ländernas register. Då namnregistrering kan ske på olika sätt i respektive land, t.ex. genom annorlunda stavning eller olika antal förnamn, är systemet inte helt vattentätt. Även efter manuella genomgångar där namnuppsättningar jämförs kan det hända att ett fåtal personer inte betraktas som matchande och därför inte kommer med i statistiken fast de borde ha räknats med.

\section{Sekretess}

Utlämnandeprövning ur sekretessynpunkt har skett vid respektive statistikmyndighet eller av därför särskilt utsedd funktion i landet. Vid denna prövning har värdet av att få en statistisk bild av arbetsflöden mellan de nordiska länderna och att åstadkomma en förbättrad statistik i respektive land vägts mot det faktum att materialet överlämnas till en annan nordisk statistikmyndighet. I samtliga fall har tillstånd givits för utlämning av material utom ett fall. Den finska lagstiftningen tillåter inte utlämnande av uppgifter om enskilda personer till annat land, vilket har resulterat $i$ att en särskild lösning har fått tillämpas i kontakterna med Finland. Resultaten publiceras enbart i form av tabeller där enskilda personer inte kan identifieras.

\section{Sambearbetning av registerinformation}

\section{Steg 1. Identifiering av eventuella arbetspendlare}

Utlämnandeprövning ur sekretessynpunkt har skett vid respektive statistikmyndighet eller av därför särskilt utsedd funktion i landet. Vid denna prövning har värdet av att få en statistisk bild av arbetsflöden mellan de nordiska länderna och att åstadkomma en förbättrad statistik i respektive land vägts mot det faktum att materialet överlämnas till en annan nordisk statistikmyndighet. I samtliga fall har tillstånd givits för utlämning av material utom i Finlands fall.

Steg 2. Utlämnande av bakgrunds- och arbetsmarknadsdata data från det eventuella bostadslandet (land B)

I bostadslandet (land B) matchas födelsedatum och namn mot befolkningsregistret för att se vilka som är folkbokförda där. För de personer som identifierats i bostadslandet framställs ett dataset med demografiska uppgifter och uppgifter om personen även har ett arbete i bostadslandet. Detta material lämnas till arbetslandet, oh omfattar således de personer som återfunnits som folkbokförda i land B och som haft arbete i land A. 
Därmed vet man hur många personer som bor i land $\mathrm{B}$ och som haft ett anställningsförhållande i land A.

Steg 3. Komplettering med data från arbetslandet (land A)

När materialet återkommer till arbetslandet kompletteras det med data om personernas arbete i arbetslandet. Därmed är möjligt att avgöra i vilket land som personernas huvudsakliga arbete bedrivits. Utifrån dessa uppgifter fastställs vilka personer som skall klassificeras som arbetspendlare över riksgräns. När detta arbete är färdigt sänds det aktuella materialet till bostadslandet (land B).

Steg 4. Ett komplett material sänds åter till bostadslandet (land B)

I och med att bostadslandet erhållit det färdiga materialet från arbetslandet är det möjligt att redovisa statistik om den aktuella populationen.

I bilagan Variabelbeskrivning för arbetspendling över riksgräns redovisas variabelutbytet i detalj.

\section{Löntagare med inkomst $\mathrm{i}$ annat land}

Begreppet löntagare med inkomst i ett annat land omfattar dels de personer som klassats som arbetspendlare över riksgränsen, dels övriga löntagare med inkomst i landet.

Detta begrepp ger en helhetsbild av flödet av arbetsinkomster över en riksgräns. I redovisningen ingår förutom antalsredovisningar av antalet personer även tabeller över lönesummor m.m.

\section{Arbetpendlare över riksgräns, klassificering}

För att räknas som arbetspendlare över riksgräns ska den aktuella personen inneha ett jobb som täcker november månad när Sverige är arbetslandet och i december när arbetslandet är Finland. Dessutom ska en eventuell inkomst $\mathrm{i}$ hemlandet överstiga inkomsten $\mathrm{i}$ arbetslandet för samma kalenderår. Antalet arbetspendlare är en delmängd av antalet löneinkomsttagare 